\title{
Baseline Concept Description of a Small Modular High Temperature Reactor
}

\author{
Hans D. Gougar
}

May 2014

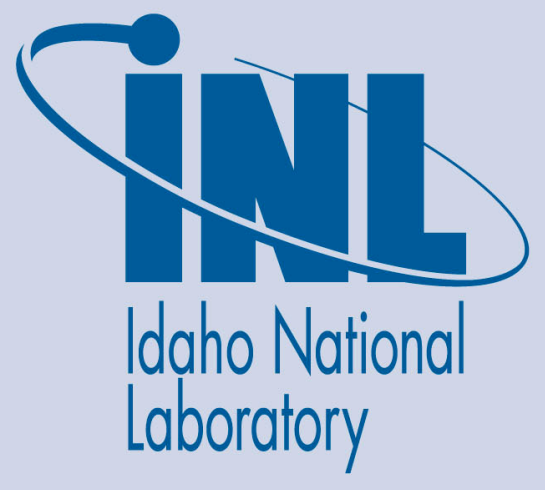

The INL is a U.S. Department of Energy National Laboratory operated by Battelle Energy Alliance 


\section{DISCLAIMER}

This information was prepared as an account of work sponsored by an agency of the U.S. Government. Neither the U.S. Government nor any agency thereof, nor any of their employees, makes any warranty, expressed or implied, or assumes any legal liability or responsibility for the accuracy, completeness, or usefulness, of any information, apparatus, product, or process disclosed, or represents that its use would not infringe privately owned rights. References herein to any specific commercial product, process, or service by trade name, trade mark, manufacturer, or otherwise, does not necessarily constitute or imply its endorsement, recommendation, or favoring by the U.S. Government or any agency thereof. The views and opinions of authors expressed herein do not necessarily state or reflect those of the U.S. Government or any agency thereof. 


\title{
Baseline Concept Description of a Small Modular High Temperature Reactor
}

\author{
Hans D. Gougar
}

May 2014

\author{
Idaho National Laboratory \\ Very High Temperature Reactor \\ Technology Development Office \\ Idaho Falls, Idaho 83415 \\ http://www.inl.gov
}

Prepared for the U.S. Department of Energy Office of Nuclear Energy Under DOE Idaho Operations Office Contract DE-AC07-05ID14517 



\title{
Baseline Concept Description of a Small Modular High Temperature Reactor
}

\author{
INL/EXT-14-31541
}

May 2014
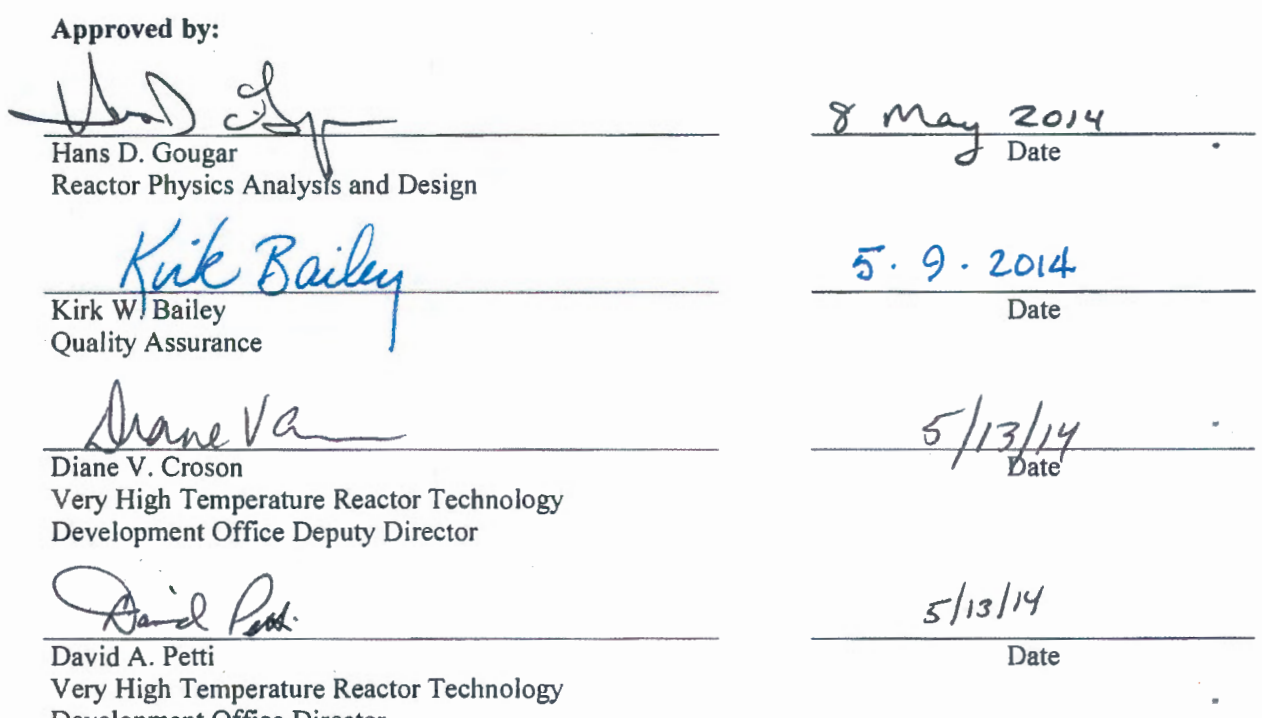

Very High Temperature Reactor Technology

Development Office Director 



\section{EXECUTIVE SUMMARY}

The objective of this report is to provide a description of generic small modular high temperature reactors (herein denoted as smHTR), summarize their distinguishing attributes, estimate the technical readiness, and lay out the research and development (R\&D) required for commercialization. The generic concepts rely heavily on the modular high temperature gas-cooled reactor designs developed in the 1980s that were never built but for which pre-licensing or certification activities were conducted. The concept matured more recently under the Next Generation Nuclear Plant (NGNP) project, specifically in the areas of fuel and material qualification, methods development, and licensing. As all vendor-specific designs proposed under NGNP were all both 'small' or medium-sized and 'modular' by International Atomic Energy Agency (IAEA) and Department of Energy (DOE) standards, the technical attributes, challenges, and R\&D needs identified, addressed, and documented under NGNP are valid and appropriate in the context of Small Modular Reactor (SMR) applications.

The format of the report roughly follows that of the Technical Review Panel report submitted to the Department of Energy (DOE) in September of 2012. Part 1 provides the general background and overview of the HTR, part 2 consists mainly of a table listing the important technical parameters and features of the reference concepts, part 3 includes a table showing the technical readiness of the major systems, structures, and components and the estimated costs to build a plant, and part 4 describes the attributes of the concepts in terms of the Technical Review Panel Criteria specified in the TRP report.

Although the term High Temperature Reactor (HTR) is commonly used to denote graphite-moderated, thermal spectrum reactors with coolant temperatures in excess of $650^{\circ} \mathrm{C}$ at the core outlet, in this report the historical term High Temperature Gas-Cooled Reactor (HTGR) is used to distinguish the gas-cooled technology described herein from its liquid salt-cooled cousin. Moreover, in this report it is to be understood that the outlet temperature of the helium in an HTGR has an upper limit of $850^{\circ} \mathrm{C}$, which corresponds to the temperature to which certain alloys are currently being qualified under DOE's Advanced Reactor Concepts (ARC) program. Although similar to the HTGR in just about every respect, the Very High Temperature Reactor (VHTR) may have an outlet temperature in excess of $850^{\circ} \mathrm{C}$ and is therefore farther from commercialization because of the challenges posed to materials exposed to these temperatures. The VHTR is the focus of R\&D under the Generation IV program and its specific R\&D needs are included in this report when appropriate for comparison.

The distinguishing features of the modular HTGR are the refractory (TRISO) coated particle fuel, the low-power density, graphite-moderated core, and the high outlet temperature of the inert helium coolant. The low power density and fuel form effectively eliminate the possibility of core melt, even upon a complete loss of coolant pressure and flow. The graphite, which constitutes the bulk of the core volume and mass, provides a large thermal buffer that absorbs fission heat such that thermal transients occur over a timespan of hours or even days. As chemically-inert helium is already a gas, there is no coolant temperature or void feedback on the neutronics and no phase change or corrosion product that could degrade heat transfer. Furthermore, the particle coatings and interstitial graphite retain fission products such that the source terms at the plant boundary remain well below actionable levels under all anticipated nominal and off-normal operating conditions. These attributes enable the reactor to supply process heat to a collocated industrial plant with negligible risk of contamination and minimal dynamic coupling of the facilities (Figure E-1). The exceptional retentive properties of coated particle fuel in a graphite element were first demonstrated in the DRAGON reactor, a European research facility that began operation in 1964. 


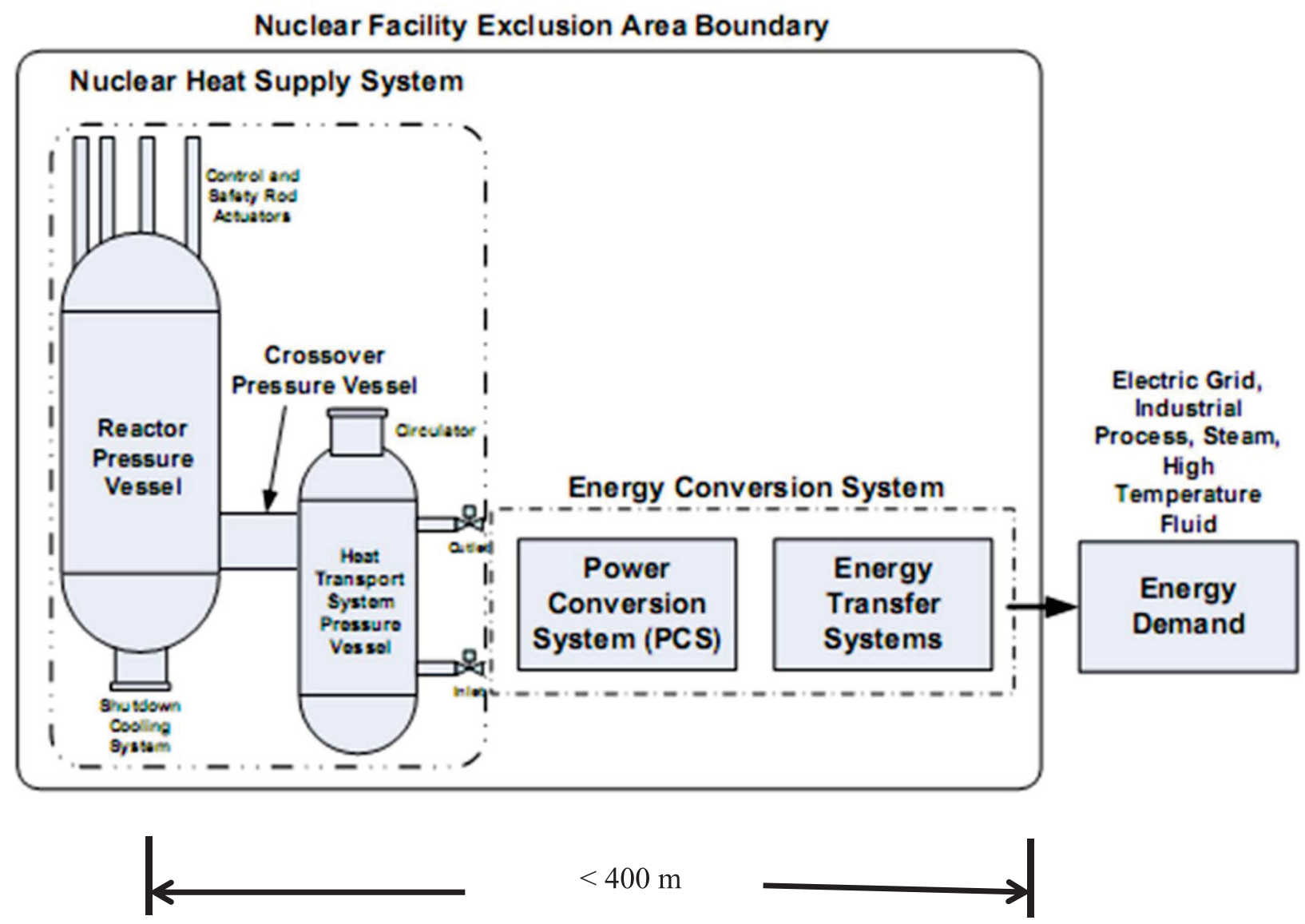

Figure E-1. Collocated smHTR and industrial plant.

Although the conceptual designs originally submitted for consideration under NGNP were originally intended to drive gas turbine (Brayton cycle) power conversion systems, feedback from industrial partners and potential NGNP customers indicated a preference for process heat in the form of steam in the $750-850^{\circ} \mathrm{C}$ temperature range. This reduced the demand to qualify the components and high temperature alloys required of high pressure, high temperature gas turbine cycles. For higher temperature applications, alloys such as $800 \mathrm{H}$ and Inc-617 were identified as suitable for vessels, heat exchangers and other metallic components with a few $(<10)$ years of additional testing and qualification. This testing started under the NGNP program and continues under ARC. The use of an indirect steam (Rankine) power conversion system does increase the risk of water ingress in the graphite core with the possibility of limited graphite interaction and elevated fission product releases. Further studies must be conducted to confirm that this would have a manageable effect on source terms. It should be noted that first generation HTGRs - notably the Arbeitsgemeinschaft Versuchs Reaktor (AVR) in Germany and Fort St. Vrain in Colorado-recovered fully from massive water ingress events and with minimal radionuclide releases. The adequacy of the steam cycle notwithstanding, the very high temperatures and inert primary coolant would support a highly efficient Brayton cycle power conversion system using either helium or supercritical carbon dioxide as a working fluid, assuming the development of a robust heat exchanger with the primary and secondary loops.

The performance of TRISO fuel underpins the passive safety case for the modular HTGR concept. The fuel developed in Germany for the first generation HTGRs showed excellent integrity and fission product retention at burnups as high as $\sim 10 \%$ FIMA and temperatures as high as $1600^{\circ} \mathrm{C}$. All HTGRs developed since then, starting with the first generation modular HTGRs in the mid-1980s, were designed 
such that the fuel temperature would never exceed this value even in the event of a complete loss of forced cooling and pressure. It should be noted that, unlike in cladding failure in light water reactors (LWRs) and other reactor concepts, exceeding the $1600^{\circ} \mathrm{C}$ 'threshold' in HTGR fuel does not result in catastrophic fuel damage. Rather, the rate of release of fission products through degraded or failed particle coatings increases and leads to increased contamination of the primary circuit and, if the primary pressure boundary is breached, actionable environmental releases. In typical modular HTGR core geometries (annular, tall and thin) with low power density and large graphite thermal inertia, the rise in fuel temperatures occurs over several hours, and only a small fraction of all fuel kernels are exposed to peak fuel temperatures in excess of $1600^{\circ} \mathrm{C}$.

Recent heating tests performed on highly irradiated fuel under the Advanced Gas Reactor (AGR) Fuel Program indicate the progress made in the design and fabrication of this fuel form. No non-negligible fission product releases were observed in statistically significant quantities of fuel particles at temperatures as high as $1800^{\circ} \mathrm{C}$, indicating a safety margin even higher than the German standard. These results will be confirmed through the additional testing planned under ARC.

Most current modular HTGR concepts are designed to burn low-enriched uranium (8-16\%) in a 'once-through' cycle to fractional burnups as high as $16 \%$. In addition to being a highly robust ('accident-tolerant') fuel form, the TRISO particle is expected to perform very well in encapsulating spent fuel in a repository. If stored in the surrounding graphite matrix, the spent fuel is high in volume but also low in heat loading. The graphite matrix, however, can be removed to leave a lower volume waste form with a correspondingly higher thermal loading. Research is underway in a number of countries into the decontamination and recycling of used graphite.

HTGRs have been fueled with thorium and other fuels. Both Fort St. Vrain (USA) and the Thorium HochTemperatur Reaktor (Germany) operated on a combination of highly enriched uranium and fertile thorium. Under the early German HTR program, a number of different closed fuel cycles were considered. A plutonium-burning HTGR has been the subject of R\&D collaboration between the U.S. and Russia as well as in Europe. TRISO fuel can be (and has been) reprocessed. Chemical removal of the graphite matrix and outer pyrolytic coating reveals the more durable silicon carbide layer which can be breached through electrical or mechanical means. Once breached, the ceramic fuel kernel can be leached out for processing via standard treatments. Proliferation concerns and the relatively low price of enriched uranium have removed any real motivation for closed cycle HTGRs. Also, as a thermal spectrum reactor, the HTGR can effectively reduce plutonium stockpiles but minor actinides will accumulate even in recycled fuel. Most new modular HTGRs and the VHTR are designed to burn only fresh low-enriched uranium (LEU) although thorium cycles are still being explored.

The graphite used in the 1st generation HTGRs no longer exists. New grades produced by a few vendors are the subject of extensive characterization and irradiation testing under the NGNP (now ARC) program. Preliminary results of these tests indicate that the quality of the newer graphite grades is superior to, and the material properties are more uniform than those of, their predecessors.

The methods used to simulate plant behavior for design and licensing have matured under the DOEs NGNP program but still lag behind the industry's ability to simulate LWRs in terms of fidelity and accuracy. Codes are being developed or updated to capture HTGR physics but there remain gaps in the neutronic and thermal fluid database needed to validate these codes and models to modern regulatory standards. A few integral and separate effects experiments are underway to fill the gaps but any design submitted under a near-term license application will need to reflect considerable safety margins to be accepted (achieved at the expense of performance).

A complete report of the status of HTGR technology (including references) is provided in the accompanying status report [1]. 
The technical barriers to small modular HTGR deployment will be largely overcome with the completion of the fuel and material qualification programs and, to a lesser extent, the experimental confirmation of thermal fluid behavior under accident conditions. The major non-technical challenges are licensing and economics. Licensing is inhibited by the LWR-centric requirements in the federal regulations, the lack of extensive operating plant and experimental data, the approximate models used in simulation, and the lack of familiarity with the HTGR among regulators. The economic challenge arises from: (1) the lack of an industrial infrastructure supporting HTGR fuel and plant manufacturing, (2) the uncertainties in modeling that must be compensated by more conservative designs, and (3) the availability of inexpensive fossil fuels for electricity generation, transportation and heating, and industrial process heat. 


\section{CONTENTS}

EXECUTIVE SUMMARY vii

ACRONYMS xiii

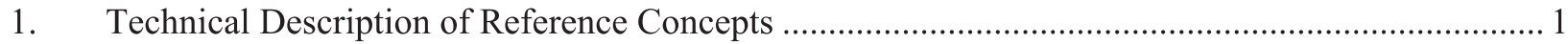

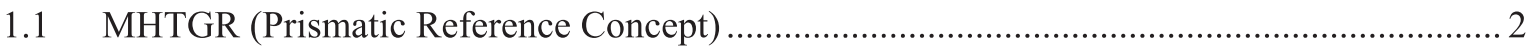

1.2 HTR Modul (Pebble Bed Reference Concept)................................................................. 7

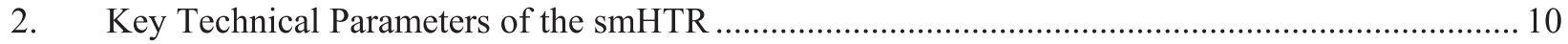

3. Technical Readiness and Estimated Costs.......................................................................... 14

4. Attributes of the smHTR per the Technical Review Panel Criteria ............................................ 16

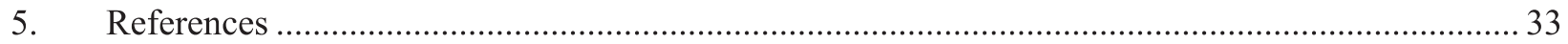

\section{FIGURES}

Figure E-1. Collocated smHTR and industrial plant...............................................................................iii

Figure 1. TRISO fuel as loaded into a prismatic or PBR..................................................................... 2

Figure 2. Schematic of the MHTGR power plant (best available drawing). .............................................. 3

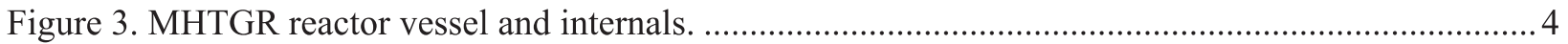

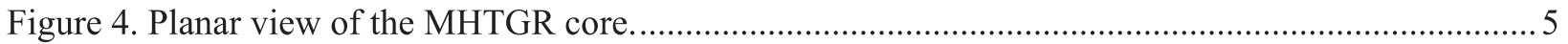

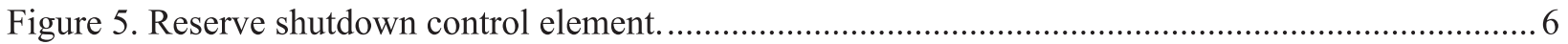

Figure 6. Major features of the HTR-PM (China) variant of the HTR Modul. ......................................... 7

Figure 7. Layout of the HTR-PM (Modul) vessel and steam generator ................................................ 8

Figure 8. Peak fuel temperature during pressurized and depressurized loss of forced cooling transients.

\section{TABLES}

Table 1: Summary of features for the two smHTR concepts. 10

Table 2: Technology Readiness Levels for Major SSCs for a VHTR with a $950^{\circ} \mathrm{C}$ Outlet Temperature.

Table 3. TRLs for major components in the AREVA reference design with a $750^{\circ} \mathrm{C}$ outlet

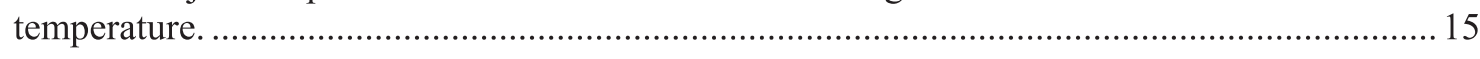

Table 4: Cost Summary for NGNP and NOAK HTGR with a Rankine power cycle, $850^{\circ} \mathrm{C}$ ROT.......... 16

Table 5: Summary of Features by TRP Criteria 16 


\section{ACRONYMS}

AGR Advanced Gas Reactor

ARC Advanced Reactor Concepts

AVR Arbeitsgemeinschaft Versuchs Reaktor

BOP Balance of Plant

CANDU Canadian Deuterium/Uranium

CFD Computational Fluid Dynamics

CR Control rods

DOE Department of Energy

FBP Fixed Burnable Poison

FP Fission Products

GA General Atomics

HLW High level waste

HTR High Temperature Reactor

HTTR High Temperature engineering Test Reactor

I\&C Instrumentation and control

IAEA International Atomic Energy Agency

IPyC Inner pyrolitic carbon

KMP Key measurement points

LBP Lumped Burnable Poison

LEU low enriched uranium

LWR Light water reactors

MHTGR Modular High Temperature Gas Reactor

NOAK Nth-of-a-kind

NGNP Next Generation Nuclear Plant

NRC Nuclear Regulatory Commission

OPyC Outer pyrolitic carbon

PBMR Pebble Bed Modular Reactor

PBR Pebble bed reactor

PCS Power Conversion System

R\&D Research and development

RCCS Reactor Cavity Cooling System

RSC Reserve shutdown control

RSS Reserve shutdown system 
SMR Small Modular Reactor

SSC Systems, structures, and component

TDRM technology development roadmap

TRISO tristructural isotropic

UCO Uranium Carbide/Oxide

VHTR Very High Temperature Reactor

VSOP Very Superior Old Programs 


\section{Baseline Concept Description of a Small Modular High Temperature Reactor}

\section{Technical Description of Reference Concepts}

Although they share the attributes described above, two design variants of the modular HTGR have been developed and are sufficiently different in other aspects to be described in parallel in this report as separate reference concepts (Figure 1). General Atomics (GA) began development of the prismatic (block) modular HTGR in the 1960s and, with support from the U.S. government, pursued variations of the concept in support of different missions. Two HTGRs designed by GA - the $115 \mathrm{MWt}$ Peach Bottom-1 and the $750 \mathrm{MWt}$ Fort St.Vrain - delivered power to the U.S. grid. One prismatic reactor is in operation today, the $30 \mathrm{MWt}$ High Temperature engineering Test Reactor (HTTR), built by the Japan Atomic Energy Agency and located at the Oarai Research Laboratory. In the 1980s, GA developed the Modular High Temperature Gas Reactor (MHTGR) and commenced preliminary licensing activities with the Nuclear Regulatory Commission (NRC). The MHTGR is the basis of the prismatic reference concept described in this paper.

The other class of HTGR is the pebble bed reactor (PBR) pioneered in Germany, following roughly the same development trajectory as the prismatic core. The $46 \mathrm{MWt}$ Arbeitsgemeinschaft VersuchsReaktor operated for 20 years, primarily as a demonstration system and a testbed for pebble fuel but it also delivered power to the grid. It was succeeded by the Thorium HochTemperatur Reaktor (THTR), which operated only for a few years but also generated electricity. One PBR is in operation today, the 10 MWt HTR-10, built by China's Institute for Nuclear Energy Technology. In the 1980s, Interatom, a German industrial consortium, commenced licensing activities (in Germany) on the HTR Modul, a $200 \mathrm{MWt}$ modular PBR design that featured online fueling. China adopted this design and is in the process of building a two-unit plant that is scheduled to commence operation in 2016. The HTR Modul is the basis of the pebble bed reference concept described in this paper.

Neither the MHTGR nor the HTR Modul would require active decay heat removal to ensure fuel integrity. The TRISO-coated particle fuel, the large graphite mass, low power density, and natural heat removal mechanisms are sufficient to maintain fuel integrity under all postulated scenarios.

As of 2014, no TRISO fuel form is qualified for commercial use in the U.S. Under the Next Generation Nuclear Plant (NGNP)/Advanced Gas Reactor (AGR) (now Advanced Reactor Concepts [ARC]) program and in cooperation with a fuel vendor, TRISO fuel is being qualified through a series of irradiations and heating tests under an ASME NQA-1-2008; 1a -2009 program. Any near-term smHTR project outside of China will therefore be constrained to use AGR fuel. For this reason, it is assumed that AGR fuel will be used for both of the reference concepts.

Tristructural-Isotropic (TRISO) fuel particles are bonded in a graphite matrix to form either a cylindrical 'compact' or a spherical pebble (Figure 1). TRISO particles consist of various layers acting in concert to provide a containment structure that limits radioactive product release. They include a fuel kernel, porous carbon layer, inner pyrolitic carbon (IPyC), SiC, and outer pyrolitic carbon (OPyC). The buffer layer allows for limited kernel migration and provides some retention of gas compounds. The silicon carbide layer ensures the structural integrity of the particle under constant pressure and also helps retain metallic fission products. Details of the TRISO particle and compact designs are given in table 1 in part 2. Compacts are inserted into hexagonal graphite blocks to assemble a prismatic fuel element. For pebbles, a 5-mm layer of graphitic matrix material is forms a protective shell around the inner fueled zone (see Figure 1). 


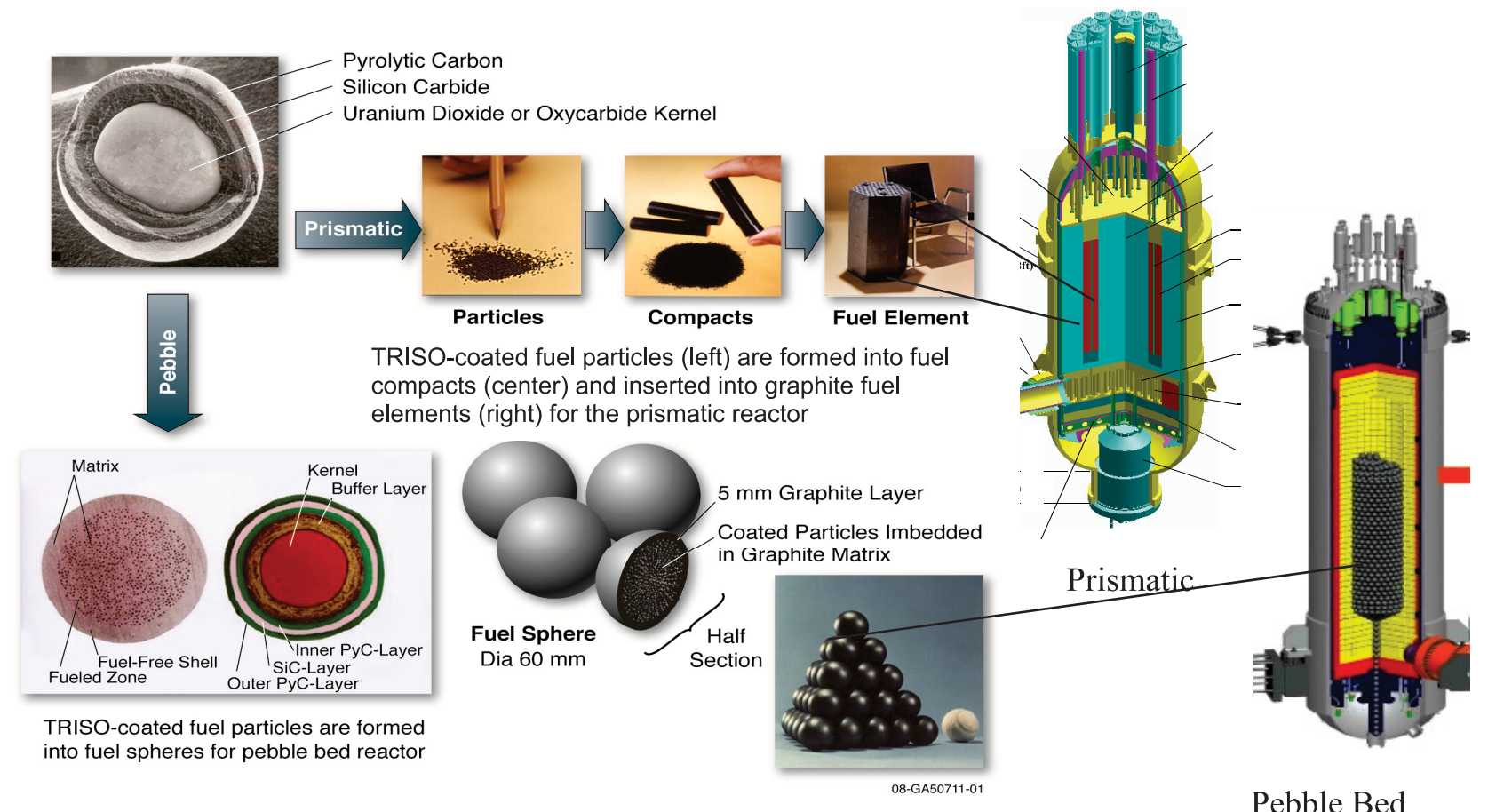

Figure 1. TRISO fuel as loaded into a prismatic or PBR.

\subsection{MHTGR (Prismatic Reference Concept)}

The MHTGR 350 is a GA design that was developed in the 1980s. The major features of the power plant are shown in Figure 2 and the main characteristics of the design are summarized in table 5 in Section 3. The reactor vessel contains the reactor core, reflectors and associated neutron control systems, core support structures, and shutdown cooling heat exchanger and motor-driven circulator. The steam generator vessel houses a helically-coiled steam generator bundle as well as the motor-driven main circulator. The pressure-retaining components are constructed of steel and designed using existing technology.

The reactor vessel is uninsulated to provide for decay heat removal under loss-of-forced-circulation conditions. In such events, heat is transported to the passive Reactor Cavity Cooling System (RCCS), which circulates outside air by natural circulation within enclosed panels surrounding the reactor vessel. No valves, fans, or other active components or operator actions are needed to remove heat using the Reactor Cavity Cooling System (RCCS).

The reactor core and the surrounding graphite neutron reflectors are supported within a steel reactor vessel. The restraining structures within the reactor vessel are a steel and graphite core support structure at the bottom and a metallic core barrel around the periphery of the side reflectors. 


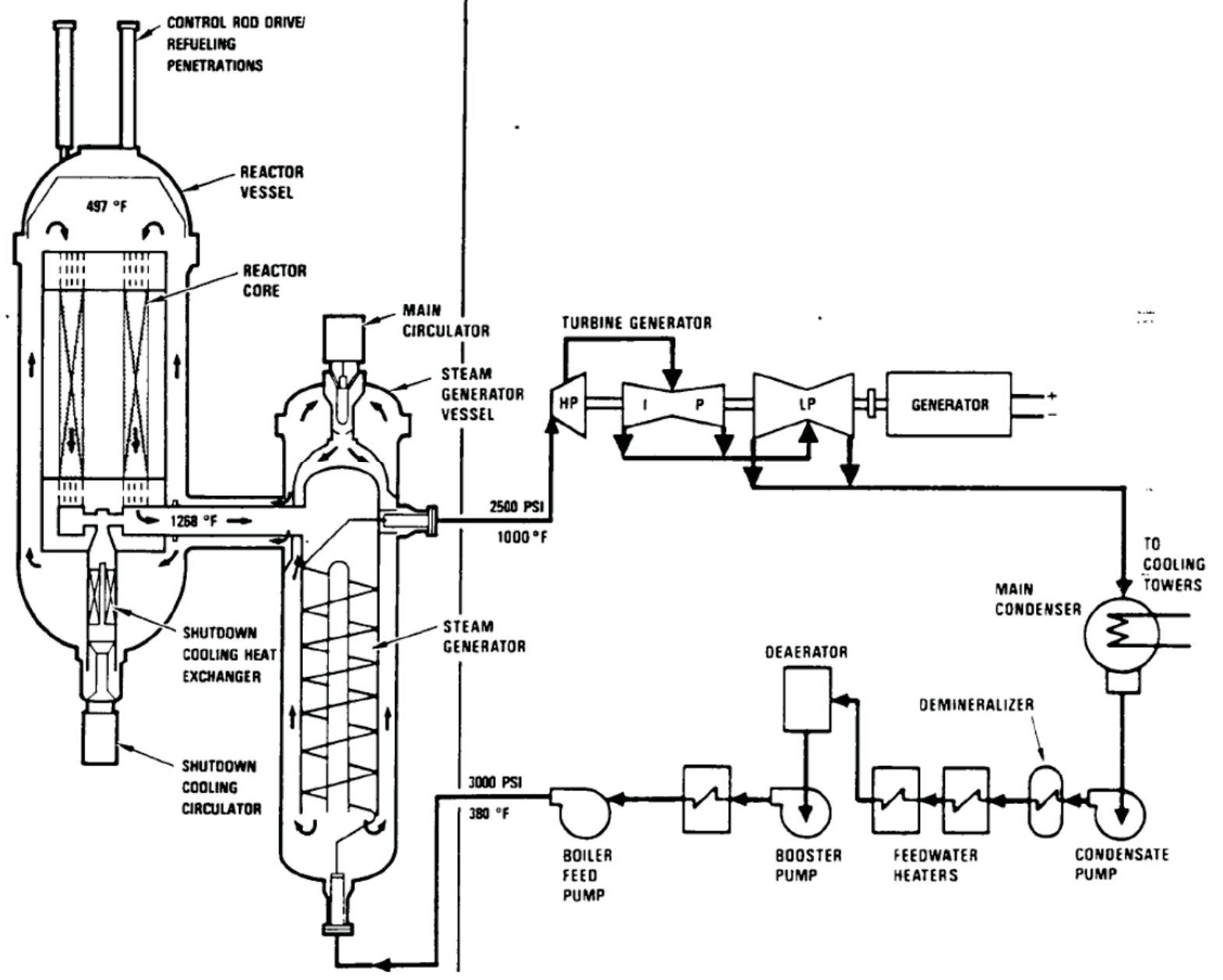

Figure 2. Schematic of the MHTGR power plant (best available drawing).

The core is designed to provide $350 \mathrm{MWt}$ at an average power density of $5.9 \mathrm{MW} / \mathrm{m}^{3}$. A core elevation view is shown in Figure 3. The design of the core consists of an array of hexagonal fuel elements in a cylindrical arrangement surrounded by a single ring of identically sized solid graphite replaceable reflector elements, followed by a region of permanent graphite reflector elements all located within a reactor pressure vessel. The permanent reflector elements contain a $10-\mathrm{cm}$ thick borated region at the outer boundary, adjacent to the core barrel. The borated region contains $\mathrm{B}_{4} \mathrm{C}$ particles of the same design as in the Fixed Burnable Poison (FBP), but dispersed throughout the entire borated region with a volume fraction of $61 \%$. 


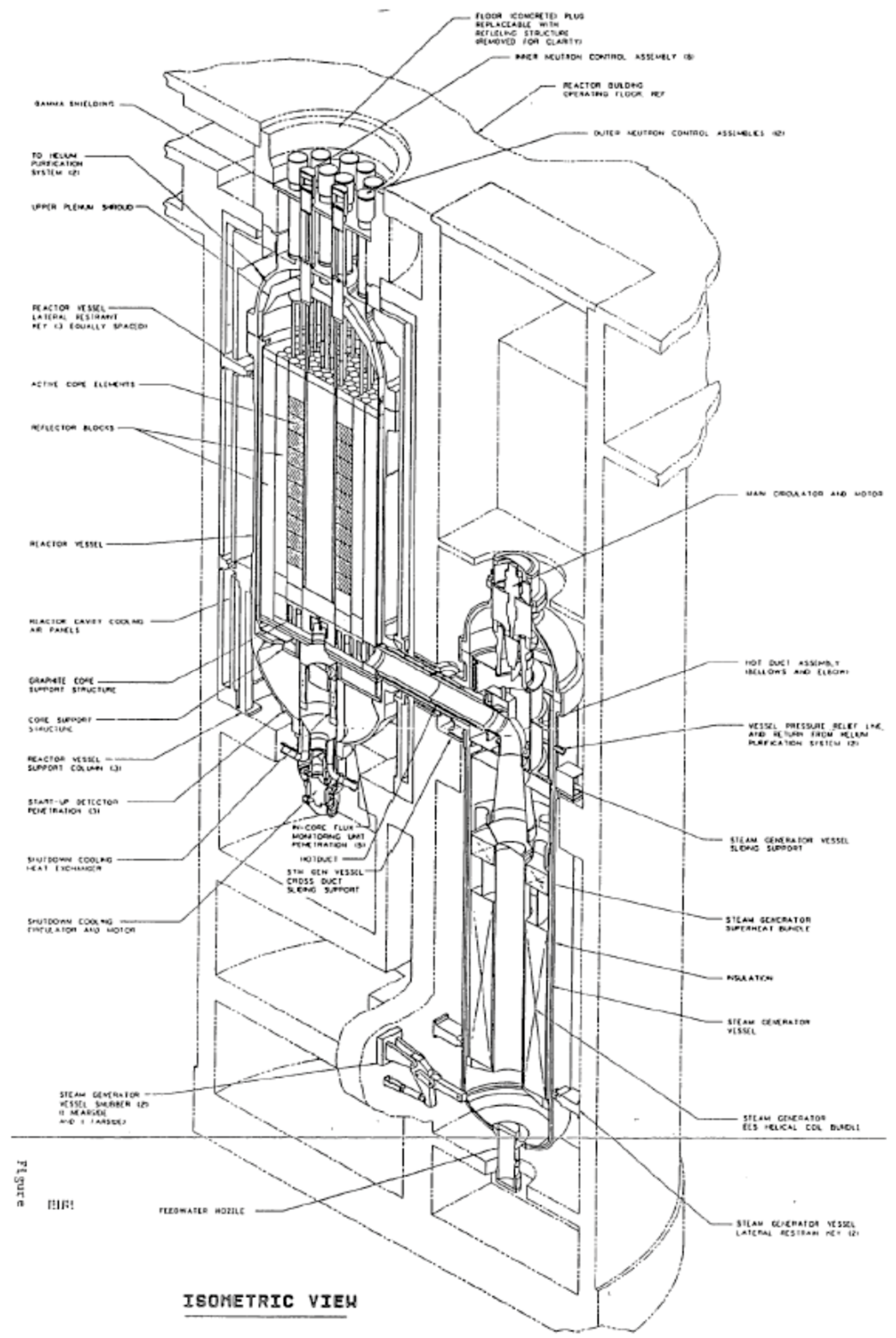

Figure 3. MHTGR reactor vessel and internals. 
The active core consists of hexagonal graphite fuel elements containing blind holes for fuel compacts and full-length channels for helium coolant flow. The fuel elements are stacked to form columns (10 fuel elements per column) that rest on support structures. The active core columns form a three-row annulus with columns of hexagonal graphite reflector elements in the inner and outer regions. Thirty reflector columns contain channels for control rods, and 12 columns in the core also contain channels for the reserve shutdown material.

The annular core configuration (Figure 4) was selected, along with the average power density of $5.9 \mathrm{MW} / \mathrm{m}^{3}$, to achieve maximum power rating and still permit passive core heat removal while maintaining the $\mathrm{SiC}$ temperature below $\sim 1600^{\circ} \mathrm{C}$ during a conduction cooldown (also known as depressurized loss-of-forced cooling) event. The active core effective outer diameter of $3.5 \mathrm{~m}$ is sized to maintain a minimum reflector thickness of $1 \mathrm{~m}$ within the $6.55-\mathrm{m}$ inner diameter reactor vessel. The radial thickness of the active core annulus was specified on the basis of ensuring that the control rod worths of the reflector located rods would meet all shutdown and operating control worth requirements. The choice of reflector control rods was made to ensure that the control rod integrity is maintained during passive decay heat removal events. These radial dimensions also allow for a lateral restraint structure between the reflector and vessel. The height of the core with ten elements in each column is $7.9 \mathrm{~m}$, which allows maximum power rating and axial power stability over the cycle.

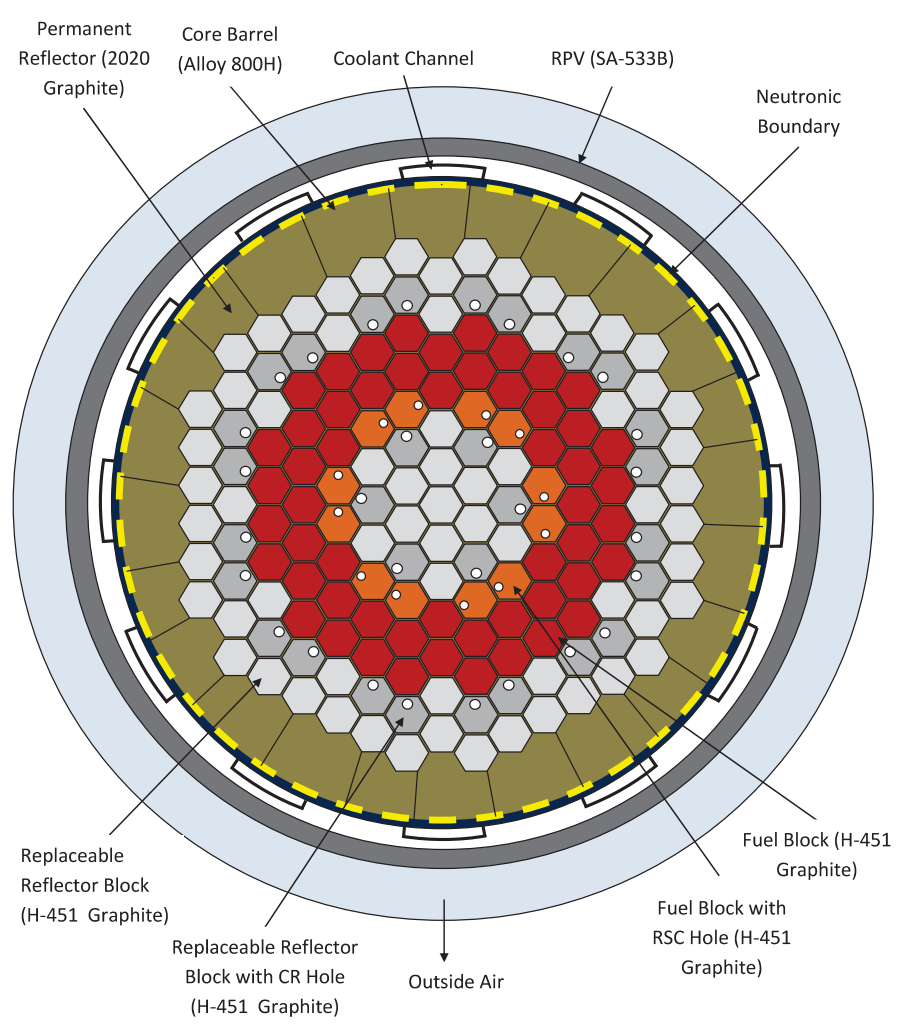

Figure 4. Planar view of the MHTGR core.

There are two types of fuel elements, a standard element, and a reserve shutdown (Figure 5) element that contains a channel for reserve shutdown control (RSC). The fuel elements are right hexagonal prisms of the same size and shape as the Fort St. Vrain HTGR elements. 

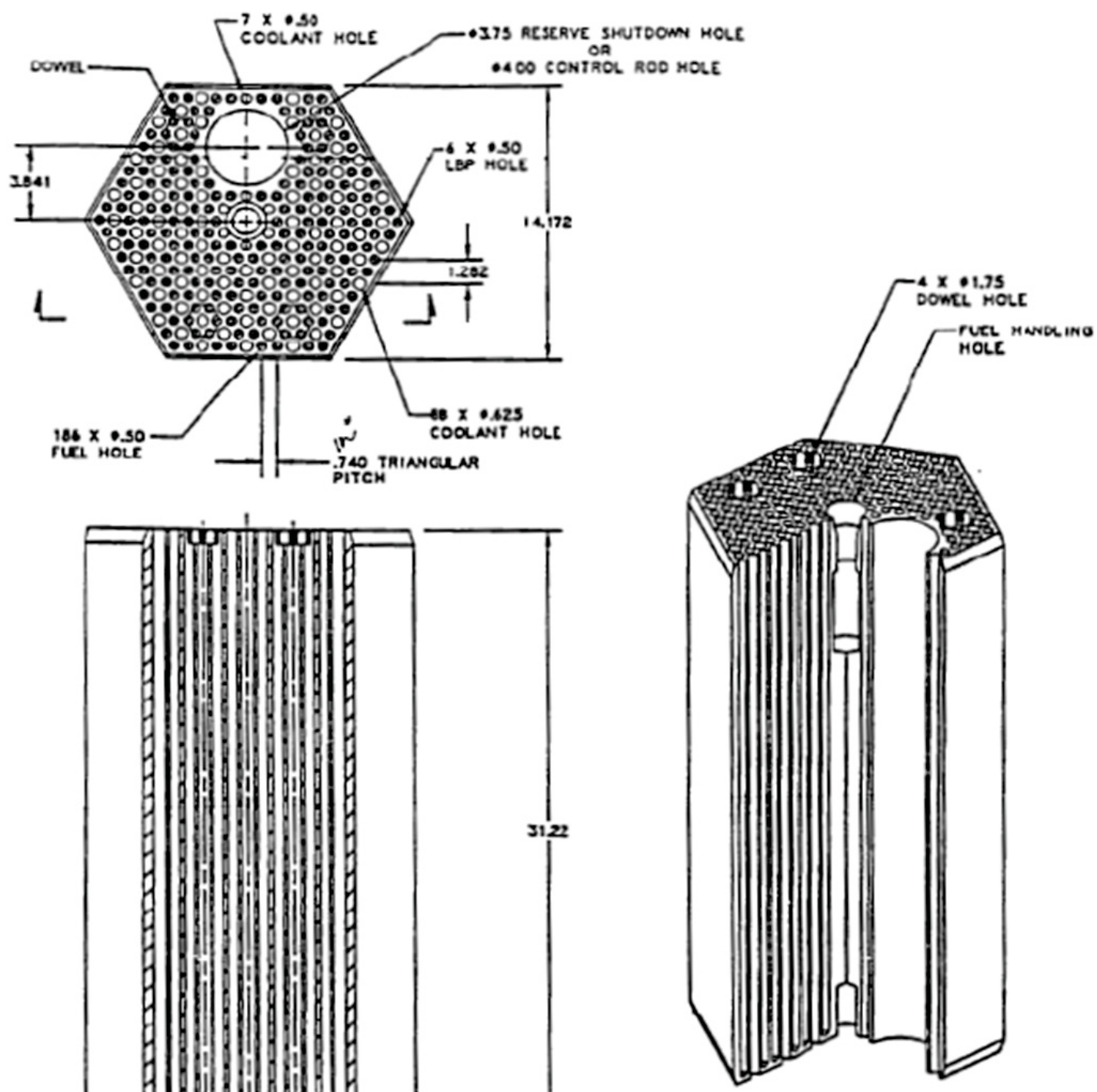

Figure 5. Reserve shutdown control element.

The fuel and coolant holes are located in parallel through the length of the element. The standard fuel element contains a continuous array of fuel and coolant holes in a regular triangular array of two fuel holes per one coolant hole. The six corner holes contain lumped burnable poison compacts.

At each element-to-element interface in a column, there are four dowel/socket connections, which provide alignment of coolant channels. A $3.5-\mathrm{cm}$ diameter fuel-handling hole, located at the center of the element, extends down about one-third of the height, with a ledge where the grapple of a fuel-handling machine engages.

The core reactivity is controlled by a combination of lumped burnable poison (LBP), movable poisons, and a negative temperature coefficient. The fixed poison is in the form of LBP compacts inserted into fuel blocks near the vertices of the hexagon. The movable poison is in the form of metal-clad control rods inserted into the inner and outer outer radial reflectors. Should the control rods become inoperable, a backup RSC is provided in the form of borated pellets that may be released into channels in the active core. Details of the control element construction are available in references [9]. 


\subsection{HTR Modul (Pebble Bed Reference Concept)}

The HTR Modul originally designed by Interatom in the 1980s is now being built, with some modifications, as a 2x250 MWt plant in China. The major features of the power plant are shown in Figure 6 and Figure 7. The reactor vessel contains the reactor core, reflectors and associated neutron control systems, core support structures, and motor-driven circulator but no shutdown cooling system. The steam generator vessel houses a helically-coiled steam generator bundle as well as the motor-driven main circulator. The pressure-retaining components are constructed of steel and designed using existing technology.

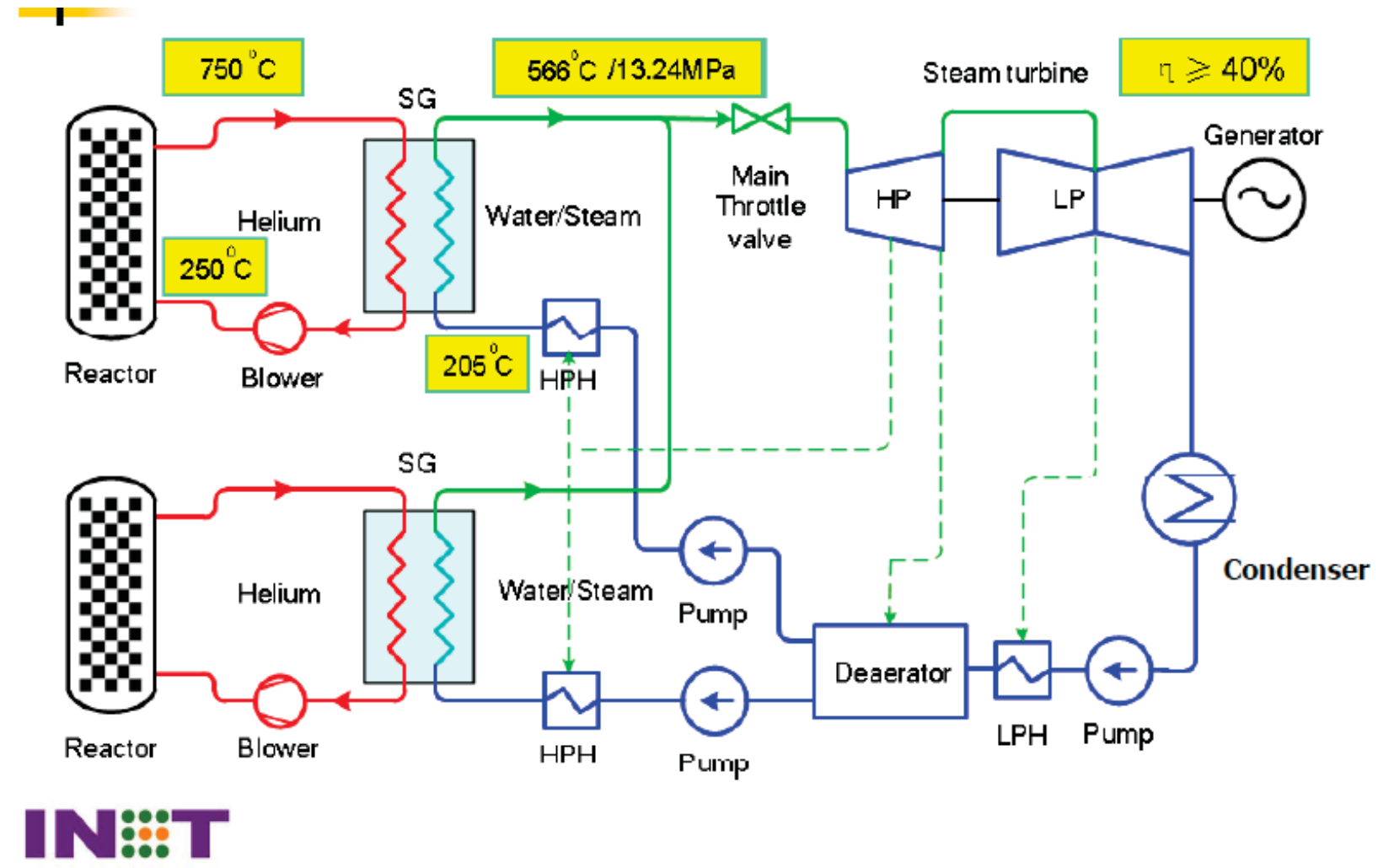

Figure 6. Major features of the HTR-PM (China) variant of the HTR Modul.

Each core is designed to provide $200 \mathrm{MWt}$ at an average power density of $3.0 \mathrm{MW} / \mathrm{m}^{3}$ [2]. The design of the core consists of cylindrical vessel lined with solid graphite replaceable reflector elements, followed by a region of permanent reflector elements all located within a reactor pressure vessel. The active core contains roughly 350,000 pebbles stochastically loaded and recirculated during operation. When a pebble drops from the bottom discharge chute, its burnup is measured. If it has not exceeded the burnup limit, it will be transferred pneumatically to the top of the core for another pass. Each pebble passes through the core about 15 times before final discharge to the spent fuel storage containers. 


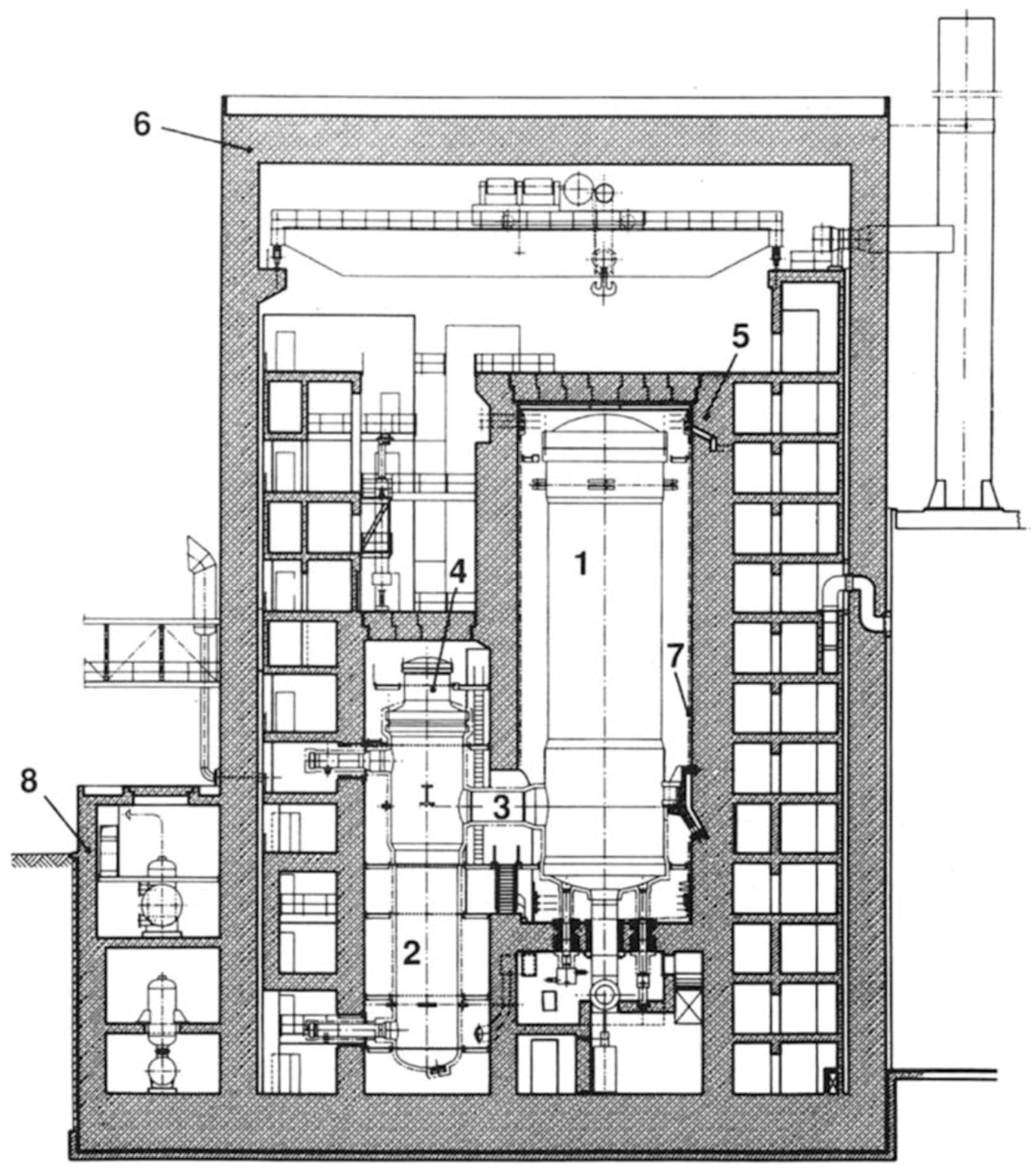

Figure 7. Layout of the HTR-PM (Modul) vessel and steam generator ${ }^{3}$

Figure Legend.

1 Reactor pressure vessel

2 Steam generator

3 Cross vessel

4 Primary circuit blower

$\begin{array}{ll}5 & \text { Primary cell } \\ 6 & \text { Concrete shield } \\ 7 & \text { Surface cooler (RCCS) } \\ 8 & \text { Reactor building annex }\end{array}$


The 3-meter diameter of the pebble bed permits passive core heat removal (via conduction and radiation) while maintaining the $\mathrm{SiC}$ temperature below $\sim 1600^{\circ} \mathrm{C}$ during a loss of forced cooling event. The 1-m graphite side reflector also serves to absorb the heat of a thermal transient, pass it to through the core barrel to the pressure vessel where is radiates to the RCCS. The diameter of the active core is limited to ensure that the combined worth of the reflector-located rods would meet all shutdown and operating reactivity requirements.

The core operates with very little excess reactivity as the online fuel system adds fresh pebbles to the core at the minimum frequency to maintain overall criticality, possibly with rods partially inserted to provide xenon-override capability if rapid restart is desired after an unplanned shutdown. Thus no burnable poisons are required to hold down reactivity. Along with the complete burnup of each pebble, this enhances fuel economy over batch-loaded cores. The low excess reactivity also inhibits the use of the reactor for weapons material production as any drop in reactivity would have immediate, negative, and observable impacts on power production and fuel consumption.

The six control rods are fabricated from boron carbide $\left(\mathrm{B}_{4} \mathrm{C}\right)$ containing $10 \mathrm{w} / \mathrm{o}$ natural boron pressed between metal tubes that form a flexible train that is lowered into the core. These operating rods are used to control the power level and can maintain the required $1 \% \Delta \rho$ shutdown margin indefinitely under hot conditions. $\mathrm{B}_{4} \mathrm{C}$ spheres are injected into 18 reflector channels to provided sufficient excess reactivity to keep the core subcritial under ambient (cold) conditions.

An inadvertent withdrawal of all control rods is a limiting reactivity event which can be controlled simply by tripping the primary coolant circulators. The subsequent temperature rise shuts down the fission reaction while the excess heat is transported to the cavity cooling system (Figure 8).

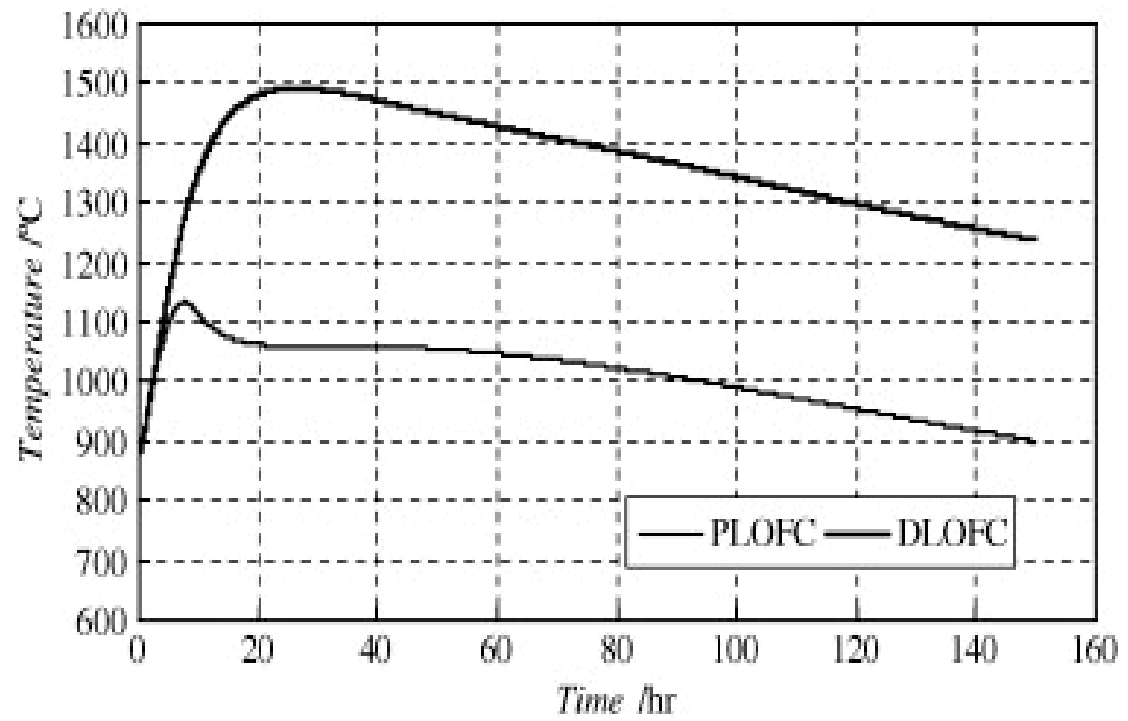

Figure 8. Peak fuel temperature during pressurized and depressurized loss of forced cooling transients [4]. 


\section{Key Technical Parameters of the smHTR}

The following table lists the major design parameters and attributes of the two concepts.

Table 1: Summary of features for the two smHTR concepts.

\begin{tabular}{|c|c|c|}
\hline & Prismatic Core & Pebble Bed Core \\
\hline \multicolumn{3}{|l|}{ 1. Plant Configuration } \\
\hline Primary System & $\begin{array}{l}\text { Reactor Pressure Vessel } \\
\text { connected to a Steam } \\
\text { General by a Coaxial Cross } \\
\text { Vessel (Duct) }\end{array}$ & $\begin{array}{l}\text { Reactor Pressure Vessel } \\
\text { connected to a Steam } \\
\text { General by a Coaxial Cross } \\
\text { Vessel (Duct) }\end{array}$ \\
\hline Intermediate Loop(s) & 1, steam & 1 , steam \\
\hline Number of Turbines & $3(\mathrm{HP}, \mathrm{IP}, \mathrm{LP})$ & $2(\mathrm{HP}, \mathrm{LP})$ \\
\hline Reactor Building Characteristics & $\begin{array}{l}\text { Below-grade } \\
\text { primary/intermediate } \\
\text { Seismic isolation for reactor }\end{array}$ & $\begin{array}{l}\text { Below-grade } \\
\text { primary/intermediate } \\
\text { Seismic isolation for } \\
\text { reactor }\end{array}$ \\
\hline \multicolumn{3}{|c|}{ 2. Energy Conversion and Balance of Plant (BOP) } \\
\hline Power Conversion Cycle & Rankine - Superheated & Rankine \\
\hline Thermal Efficiency & $38 \%$ & $40 \%$ \\
\hline Turbine Building Characteristics & \multicolumn{2}{|c|}{$\begin{array}{l}\text { Above-grade adjacent to reactor } \\
\text { No seismic isolation }\end{array}$} \\
\hline \multicolumn{3}{|l|}{ 3. Construction Techniques } \\
\hline General Approach & \multicolumn{2}{|c|}{$\begin{array}{l}\text { Traditional power plant construction enhanced with } \\
\text { modular component fabrication }\end{array}$} \\
\hline Transportability & \multicolumn{2}{|c|}{ Not significantly different than small modular LWRs } \\
\hline \multicolumn{3}{|l|}{ 4. Key Plant Parameters } \\
\hline Power (MWe/MWt) & $134 / 350$ & $80 / 200$ \\
\hline Primary Coolant & Helium & Helium \\
\hline Plant lifetime & 60 years & 60 years \\
\hline $\begin{array}{l}\text { Reactor Vessel, outer dia. (m) } \\
\text { height }(\mathrm{m})\end{array}$ & $\begin{array}{l}6.9 \\
22.5 \\
\end{array}$ & \\
\hline \multicolumn{3}{|l|}{ 5. Core Performance and Safety } \\
\hline Average Power Density (W/cc) & 5.9 & 3.0 \\
\hline Cycle Length (years) & 1.5 & Online refueling \\
\hline Capacity Factor (\%) & $>80 *$ & $>90$ \\
\hline Cycle Reactivity Loss $(\$)$ & $9^{5}$ & NA \\
\hline Fuel Enrichment (fissile/heavy metal) & $15.5 \% \mathrm{LEU}$ & 8.0 \\
\hline Initial Loading (MT of Heavy Metal) & 4.5 & 2.553 \\
\hline
\end{tabular}

\footnotetext{
${ }^{*}$ Quoted from reference 2 (1987 report)
} 


\begin{tabular}{|c|c|c|}
\hline & Prismatic Core & Pebble Bed Core \\
\hline Average/Peak Burnup (MWd/kg) & $55 / 117$ & $166^{\dagger}$ \\
\hline Peak Fast Fluence $(>0.1 \mathrm{MeV})$ & $4.4^{*} 10^{21} \mathrm{n} / \mathrm{cm}^{2}$ & $3.5^{*} 10^{21} \mathrm{n} / \mathrm{cm}^{2}$ \\
\hline Delayed Neutron Fraction & \multicolumn{2}{|l|}{ Unavailable from references } \\
\hline Power Coefficient $\left(\right.$ cents $/{ }^{\circ} \mathrm{C}$ ) & -0.5 & $\begin{array}{l}\text { Unavailable from } \\
\text { references }\end{array}$ \\
\hline Doppler Coefficient (cents $/{ }^{\circ} \mathrm{C}$ ) & \multicolumn{2}{|l|}{ Unavailable from references } \\
\hline \multicolumn{3}{|l|}{ Fuel Temperature $\left({ }^{\circ} \mathrm{C}\right)$} \\
\hline Steady-State (Mean/Peak) & $680 / 1060$ & $540 / 830$ \\
\hline DLOFC (Peak) & 1600 & 1540 \\
\hline \multicolumn{3}{|l|}{ 6. Coolant and Thermal Performance } \\
\hline Primary Coolant, $\mathrm{T}$-in $\left({ }^{\circ} \mathrm{C}\right)$ & 259 & 250 \\
\hline T-out $\left({ }^{\circ} \mathrm{C}\right)$ & 687 & 750 \\
\hline Primary Coolant, Pressure (MPa) & 6.39 & 6.0 \\
\hline Primary Coolant Purification & \multicolumn{2}{|c|}{$\begin{array}{l}\text { Helium Purification System (charcoal beds, molecular } \\
\text { sieve, oxidation bed, compressors, filters) }\end{array}$} \\
\hline Primary Coolant Corrosion Control & Unavailable from references & $\begin{array}{l}\text { Unavailable from } \\
\text { references }\end{array}$ \\
\hline $\begin{array}{l}\text { Primary Pumping Power } \\
\text { Coolant Flow Rate }\end{array}$ & $\begin{array}{l}2 \times 360 \mathrm{~kW} \\
157.1 \mathrm{~kg} / \mathrm{s} \\
\end{array}$ & $85 \mathrm{~kg} / \mathrm{s}$ \\
\hline Secondary Coolant, $\mathrm{T}$-in $\left({ }^{\circ} \mathrm{C}\right)$ & 293 & 170 \\
\hline T-out $\left({ }^{\circ} \mathrm{C}\right)$ & 541 & 530 \\
\hline $\begin{array}{l}\text { Secondary Coolant, Pressure }(\mathrm{MPa}) \\
\text { Feedwater/Steam outlet }\end{array}$ & $21.0 / 17.3$ & 19 \\
\hline \multicolumn{3}{|l|}{ 7. Fuel Properties } \\
\hline Fuel Type & \multicolumn{2}{|c|}{ TRISO-coated particles in a carbon matrix } \\
\hline Fuel Kernel & \multicolumn{2}{|l|}{$\mathrm{UC}_{0.4} \mathrm{O}_{1.5}\left(\mathrm{UO}_{2} / \mathrm{UC} / \mathrm{UC}_{2}\right.$ mixture $)$} \\
\hline outer dia. $(\mu \mathrm{m})$ & \multicolumn{2}{|l|}{425} \\
\hline Density $\left(\mathrm{g} / \mathrm{cm}^{3}\right)$ & \multicolumn{2}{|l|}{10.8} \\
\hline Coatings & \multicolumn{2}{|l|}{$\begin{array}{l}\text { TRISO } \\
\text { Thickness }(\mathrm{mm}) / \text { Density }\left(\mathrm{g} / \mathrm{cm}^{3}\right)\end{array}$} \\
\hline Buffer (carbon) & \multicolumn{2}{|l|}{$100 / 1.05$} \\
\hline Inner Pyrolytic Carbon & \multicolumn{2}{|l|}{$40 / 1.90$} \\
\hline Silicon Carbide & \multicolumn{2}{|l|}{$35 / 3.19$} \\
\hline Outer Pyrolytic Carbon & \multicolumn{2}{|l|}{$40 / 190$} \\
\hline Fuel & Cylindrical Compact in Block & Spherical Pebble \\
\hline Dimensions $(\mathrm{cm})$ & $4.928 \mathrm{~cm}$ (height) & $3.0 \mathrm{~cm}$ \\
\hline
\end{tabular}

\footnotetext{
${ }^{\dagger}$ With online fueling, each pebble attains the target burnup (within 7\%)
} 


\begin{tabular}{|c|c|c|}
\hline & Prismatic Core & Pebble Bed Core \\
\hline & $0.6225 \mathrm{~cm}$ (radius) & (radius) \\
\hline $\begin{array}{l}\text { Number of particles per element } \\
\text { packing fraction }\end{array}$ & $\begin{array}{l}5986 \\
35 \% \\
\end{array}$ & $\begin{array}{l}19000 \\
9.5 \% \\
\end{array}$ \\
\hline Matrix density $\left(\mathrm{g} / \mathrm{cm}^{3}\right)$ & 1.75 & 1.75 \\
\hline Number elements in the core & $\sim 2035800$ & 360000 \\
\hline Fuel Block & & NA \\
\hline Height/Distance across flat $(\mathrm{cm})$ & $79.3 / 36$ & \\
\hline Number Fuel holes, Standard/RSC & 210,186 & \\
\hline Fuel hole radius $(\mathrm{cm})$ & $0.635 \mathrm{~cm}$ & \\
\hline $\begin{array}{l}\text { Number Large Coolant holes, } \\
\text { Standard/RSC }\end{array}$ & $102 / 88$ & \\
\hline $\begin{array}{l}\text { Number Large Coolant hole radius } \\
(\mathrm{cm})\end{array}$ & $0.794 \mathrm{~cm}$ & \\
\hline $\begin{array}{l}\text { Number Small Coolant holes, } \\
\text { Standard/RSC }\end{array}$ & $6 / 7$ & \\
\hline $\begin{array}{l}\text { Number Small Coolant hole radius } \\
(\mathrm{cm})\end{array}$ & $0.635 \mathrm{~cm}$ & \\
\hline Fuel/Coolant Pitch & $1.8796 \mathrm{~cm}$ & \\
\hline LBP holes, diameter & $6,1.143 \mathrm{~cm}$ & \\
\hline Number per core, Standard/RSC & $540 / 120$ & \\
\hline Reflector Control Rods (Inner/Outer) & $6 / 24$ & $\mathrm{NA} / 6$ \\
\hline Reserve Shutdown Channels & 12 & 18 \\
\hline Sphere diameters $(\mathrm{mm}) / \mathrm{w} / \mathrm{o} \mathrm{B}_{4} \mathrm{C}$ & Not available $/ 40 \%$ & $10 / 10 \%$ \\
\hline Fuel Handling Machine & $\begin{array}{l}\text { Transportable (not reside at } \\
\text { site) } \\
\text { In-vessel pantograph design } \\
\text { located in single rotating plug }\end{array}$ & $\begin{array}{l}\text { Onsite Fuel Handling } \\
\text { Machine }\end{array}$ \\
\hline \multicolumn{3}{|l|}{ 9. Safety Systems } \\
\hline Emergency Heat Removal & \multicolumn{2}{|c|}{$\begin{array}{l}\text { Shutdown Heat Removal system (if available) and } \\
\text { conduction through core structures and thermal radiative } \\
\text { heat transfer across gaps to the RCCS }\end{array}$} \\
\hline Reactor Shutdown Systems & \multicolumn{2}{|c|}{ Two independent control rod groups } \\
\hline Inherent Safety Potential & \multicolumn{2}{|c|}{$\begin{array}{l}\text { Fission products are adequately retained in the fuel element } \\
\text { under any conceivable loss of forced cooling event }\end{array}$} \\
\hline \multicolumn{3}{|l|}{ 10. Containment System } \\
\hline Primary Containment Boundary & TRISO (SiC) coating & \\
\hline Secondary Confinement & \multicolumn{2}{|c|}{ Graphite element/Primary Coolant pressure boundary } \\
\hline Functional Containment Design Basis & \multicolumn{2}{|l|}{ See the note following this table. } \\
\hline
\end{tabular}




\begin{tabular}{|c|c|c|}
\hline & Prismatic Core & Pebble Bed Core \\
\hline \multicolumn{2}{|l|}{ 11. Decay Heat Management } & \\
\hline Normal Decay Heat Removal Path & \multicolumn{2}{|c|}{$\begin{array}{l}\text { Power operation: Intermediate loop, through the BOP } \\
\text { A shutdown cooling system connected to a separate heat } \\
\text { exchanger is activated at low power }\end{array}$} \\
\hline $\begin{array}{l}\text { Backup Heat Removal System Design } \\
\text { (RCCS) }\end{array}$ & \multicolumn{2}{|c|}{$\begin{array}{l}\text { Natural circulation-driven air-cooled cavity cooling panels } \\
\text { (RCCS) - not necessary to maintain fuel integrity, only } \\
\text { vessel }\end{array}$} \\
\hline Backup Decay Heat Removal Capacity & $\begin{array}{l}1.75 \mathrm{MWt}(0.5 \% \text { rated } \\
\text { power })\end{array}$ & $\begin{array}{l}0.85 \mathrm{MWt}(0.425 \% \text { rated } \\
\text { power })\end{array}$ \\
\hline Ultimate Heat Sink & \multicolumn{2}{|c|}{$\begin{array}{l}\text { Outside air through RCCS/radiative heat transfer to earth in } \\
\text { case RCCS fails }\end{array}$} \\
\hline
\end{tabular}

Functional Containment Design Basis Under the NGNP Program, a 'functional containment' approach was defined comprising several barriers that limit the release of radionuclides to the environment (source term) for each postulated event, including normal operating conditions, abnormal operating conditions, and accident conditions. Such an approach is likely to be pursued for a smHTR. The multiple barriers include:

- individual fuel particle kernels,

- fuel particle coatings,

- the fuel matrix and fuel element graphite,

- the helium pressure boundary (primary circuit), and

- a vented low-pressure reactor building.

Each of these barriers contributes to limiting the release of radionuclides to the environment to meet the NGNP Project top-level radiological criteria. The contribution of each of the barriers in limiting the transport and release of radionuclides to the environment is calculated for each postulated event, depending on the response of the reactor to the event. The top-level radiological (or "design") criteria are derived from externally imposed requirements or guidelines, such as site boundary dose limits, occupational exposure limits, Environmental Protection Agency (EPA) Protective Action Guides (PAGs), etc.

The top-level radionuclide control requirements limit calculated dose under all licensing basis events so that regulatory requirements for protection of the health and safety of the public and protection of the environment are met at an exclusion area boundary (EAB) that is no more than a few hundred meters from the reactor (e.g., 400 to 425 meters). Limits on radionuclide release from the reactor building that are consistent with these top-level radionuclide control requirements are needed to establish the target values for all of the barriers to radionuclide release and ultimately to establish allowable in-service fuel failure and as-manufactured fuel quality requirements (e.g., allowable heavy metal contamination, $\mathrm{SiC}$ coating defects, etc.).

For frequent events expected to occur within a plant's lifetime, 10 CFR $\$ 20.1301$ requires that the total effective does equivalent (TEDE) for a member of the public be limited to 100 mrem per year. For design basis events, 10 CFR $\$ 50.34(\mathrm{a})(1)$ requires that any reactor be designed such that: An individual located at any point on the EAB would not receive a radiation dose in excess of 25 rem TEDE for any 2hour period following the onset of a postulated fission product release. For beyond design basis accidents, the quantitative health objectives (QHOs) are applied as the basis for determining achievement of the NRC's "Safety Goals for the Operations of Nuclear Power Plant Operation." 
The above top-level regulatory criteria are derived from existing regulatory requirements and form the basis for NGNP operation under normal, accident, and severe accident conditions. However, the NGNP has also applied a design goal of meeting the EPA PAGs $(\leq 1 \mathrm{rem}$ TEDE or $\leq 5$ rem Thyroid dose) at the $\mathrm{EAB}$ as means of demonstrating the safety margins provided by the functional containment.

\section{Technical Readiness and Estimated Costs}

The NGNP project issued a report that documents the Technology Readiness Assessment of critical systems, structures, and components along with technology development roadmaps (TDRM) to mature the technologies needed for a high-temperature gas reactor with an outlet temperature of $950^{\circ} \mathrm{C}$, as well as other requirements consistent with those found in the NGNP requirement documents [6]. This report reconciled the assessment of Technical Readiness Levels (TRLs) and the technology development roadmaps developed by the gas reactor vendors participating in the project (AREVA, GA, Westinghouse). The results are summarized in Table 2. An update to the TDRM report was issued later in August 2009 to chart a path forward for a $750^{\circ} \mathrm{C}$ reactor outlet temperature (ROT) [7]. An assessment of reactor user interface TDRMs was also performed early in FY11 to evaluate the technology readiness of the interface components that are required to transfer high temperature heat from an HTGR to selected industrial applications [8].

Table 2: Technology Readiness Levels for Major SSCs for a VHTR with a $950^{\circ} \mathrm{C}$ Outlet Temperature.

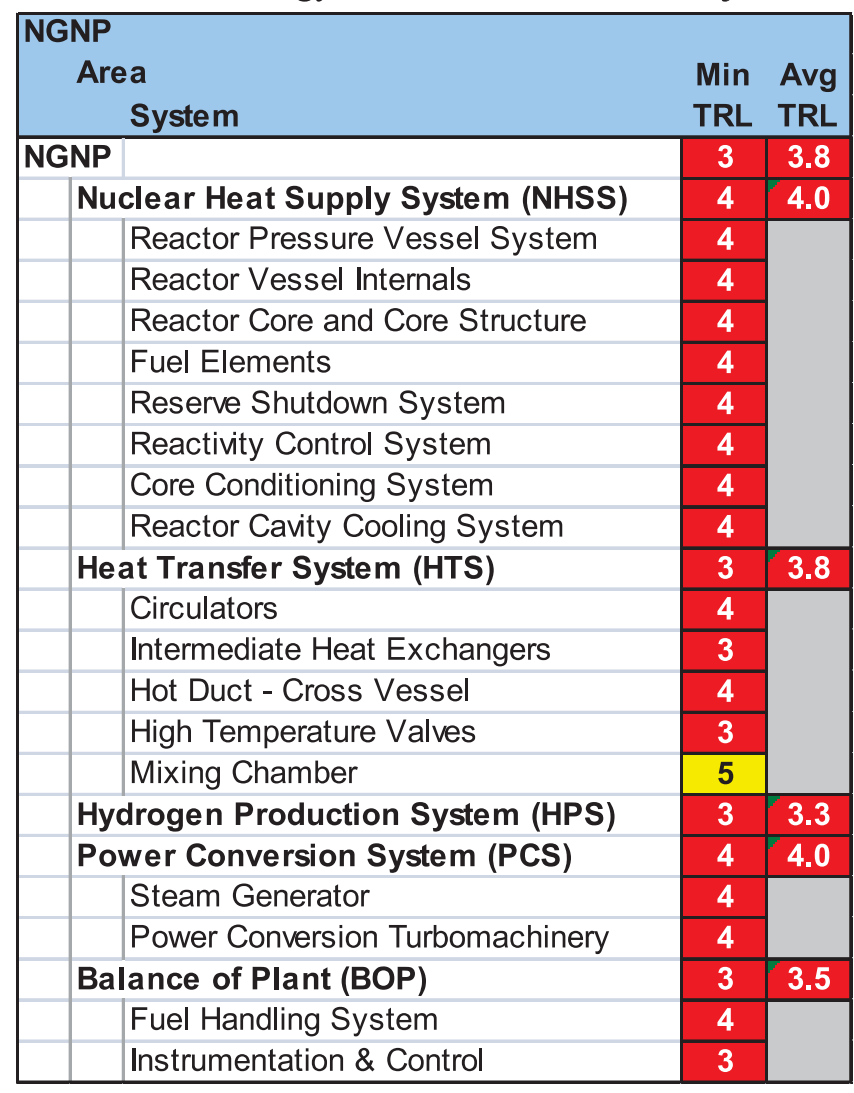

One of the vendors (AREVA) summarized the TRLs for their particular $750^{\circ} \mathrm{C}$ prismatic design that is similar to the MHTGR (Table 3). The differences between these tables clearly show the challenge of qualifying materials at the higher temperatures. The TRL for the entire plant, as given by the minimum SSC TRL is 3 for the $950^{\circ} \mathrm{C}$ VHTR and four for the $750^{\circ} \mathrm{C}$ HTGR. As the major SSCs are the same for the prismatic and pebble bed concepts, similar rankings would be expected for the HTR Modul. The values in Table 3 may be conservative as both prismatic and pebble bed commercial power plants have 
operated and that China is building a two-unit pebble bed HTGR, based upon the HTR Modul design that is scheduled to commence operation in 2016.

Table 3. TRLs for major components in the AREVA reference design with a $750^{\circ} \mathrm{C}$ outlet temperature.

\begin{tabular}{|c|c|}
\hline System, Structure, or Component & TRL \\
\hline Nuclear Heat Source & \\
- Vessel System & 7 \\
- Reactor Internals & 4 \\
- Reactor Core & 4 \\
- Nontrol Rod Drives & 4 \\
\hline Main Heat Transtrumentation & 7 \\
- Main Helium Circulator & \\
- Circulator Shutoff Valve & 6 \\
- Hot Duct & 5 \\
\hline Power Conversion System & \\
- Steam Generator & 6 \\
\hline Other Reactor Support Systems & \\
- Primary Loop Instrumentation & 6 \\
- Fuel handling System & 6 \\
\hline$\quad$ Reactivity Control System & 5 \\
\hline Process Heat Transport System & \\
- Steam Reboiler System & 8 \\
\hline
\end{tabular}

A technical evaluation [14] was prepared as part of a study for the Next Generation Nuclear Plant (NGNP) Project to address estimating the capital, operating, and decommissioning costs of a hightemperature gas-cooled reactor (HTGR). The results should be considered preliminary and are not specific to the MHTGR or HTR-Modul, but can provide a rough estimate of the costs of building those reactors today. The level of project definition for this study was determined to be an International Class 4 estimate ${ }^{\ddagger}$ with probable error range of $-30 \% /+50 \%$.

ॠ Association for the Advancement of Cost Engineering 
Table 4: Cost Summary for NGNP and NOAK HTGR with a Rankine power cycle, $850^{\circ} \mathrm{C}$ ROT.

\begin{tabular}{|c|c|c|c|c|c|c|}
\hline \multirow{3}{*}{$\begin{array}{c}\text { Reactor Phase } \\
\text { Reactor Size (MWt) } \\
\text { Number of Modules }\end{array}$} & \multicolumn{2}{|c|}{ NGNP } & \multicolumn{4}{|c|}{ NOAK } \\
\hline & \multirow{2}{*}{$\begin{array}{l}600 \\
1\end{array}$} & \multirow{2}{*}{$\begin{array}{c}350 \\
1\end{array}$} & \multicolumn{2}{|c|}{$600 \mathrm{MWt}$} & \multicolumn{2}{|c|}{$350 \mathrm{MWt}$} \\
\hline & & & 1 & 4 & 1 & 4 \\
\hline \multicolumn{7}{|l|}{ Capital Costs $\left(\$ 10^{6}\right)$} \\
\hline Preconstruction Costs & 233.50 & 233.50 & 76.50 & 91.00 & 76.50 & 91.00 \\
\hline Direct Costs & 1253.70 & 941.02 & 764.15 & 2565.53 & 543.40 & 1818.70 \\
\hline Indirect Costs & 1734.40 & 1554.73 & 459.10 & 1494.20 & 332.25 & 1065.06 \\
\hline Contingency & 644.32 & 545.85 & 259.95 & 830.15 & 190.43 & 594.95 \\
\hline Overnight Cost $\left(\$ 10^{6}\right)$ & 3865.92 & 3275.11 & 1559.70 & 4980.88 & 1142.57 & 3569.72 \\
\hline Lower Bound & 2706.14 & 2292.57 & 1091.79 & 3486.61 & 799.80 & 2498.80 \\
\hline Upper Bound & 5798.88 & 4912.66 & 2339.55 & 7471.31 & 1713.86 & 5354.57 \\
\hline Overnight Cost $(\$ / \mathrm{kWt})$ & 6443.19 & 9357.44 & 2599.50 & 2075.37 & 3264.49 & 2549.80 \\
\hline Lower Bound & 4510.24 & 6550.21 & 1819.65 & 1452.76 & 2285.14 & 1784.86 \\
\hline Upper Bound & 9664.79 & 14036.17 & 3899.26 & 3113.05 & 4896.73 & 3824.70 \\
\hline Yearly O\&M Costs $\left(\$ 10^{6}\right)$ & 37.54 & 34.39 & 37.54 & 99.60 & 34.39 & 87.00 \\
\hline Yearly O\&M Costs (\$/MWt-hr) & 7.14 & 11.22 & 7.14 & 4.74 & 11.22 & 7.09 \\
\hline Yearly Fuel Costs $\left(\$ 10^{6}\right)$ & 57.28 & 33.41 & 33.47 & 133.88 & 19.52 & 78.10 \\
\hline Yearly Fuel Costs (\$/MWt-hr) & 10.90 & 10.90 & 6.37 & 6.37 & 6.37 & 6.37 \\
\hline Decommissioning Costs $\left(\$ 10^{6}\right)$ & 122.87 & 71.67 & 122.87 & 491.47 & 71.67 & 286.69 \\
\hline
\end{tabular}

\section{Attributes of the smHTR per the Technical Review Panel Criteria}

The following table describes the concept in terms of the criteria specified in the Technology Review Panel report.

Table 5: Summary of Features by TRP Criteria

\begin{tabular}{|c|c|}
\hline Criteria & Small Modular High Temperature Reactor (smHTR) \\
\hline \multicolumn{2}{|l|}{ Category I. Safety } \\
\hline $\begin{array}{l}\text { 1) Describe design features that } \\
\text { address defense-in-depth, } \\
\text { accident prevention, accident } \\
\text { mitigation, and emergency } \\
\text { planning. }\end{array}$ & $\begin{array}{l}\text { A detailed discussion of the Defense-in-Depth approach for the NGNP is found in } \\
\text { [10]. }\end{array}$ \\
\hline $\begin{array}{l}\text { 2) Provide sufficient design } \\
\text { information on the shutdown and } \\
\text { decay heat removal systems to } \\
\text { allow an assessment of their } \\
\text { reliability. }\end{array}$ & $\begin{array}{l}\text { Shutdown: } \\
\text { In both concepts, the strong fuel temperature feedback and the large fuel temperature } \\
\text { margin during normal operation (the difference between the operating fuel } \\
\text { temperature and the temperature at which the rate of failure of fuel particles becomes } \\
\text { nonnegligible) is such that the core shuts down in response to any significant } \\
\text { temperature increase unless compensated by an external reactivity injection. Indeed, } \\
\text { the first step in one of the one of the shutdown sequences proposed for the HTR } \\
\text { Modul is to turn off the primary coolant circulating pumps followed by insertion of } \\
\text { the control rods. Rods are required, however, the keep the core in a low power or cold } \\
\text { subcritical state during maintenance. } \\
\text { The MHTGR (prismatic) features two independent sets of control rods (CR), one each } \\
\text { in the inner and outer reflector regions. The absorber material consists of } 40 \mathrm{w} / \mathrm{O} \mathrm{B}_{4} \mathrm{C} \\
\text { granules dispersed in a graphite matrix and formed into annular compacts enclosed in } \\
\text { Incoloy- } 800 \mathrm{H} \text { tubes. The boron is enriched to } 90 \text { w/o B-10. The outer reflector } \\
\text { contains } 24 \text { rods spaced evenly in the azimuthal direction. These rods are withdrawn } \\
\text { in groups of three spaced at } 120^{\circ} \text { intervals to limit azimuthal variations in power. The } \\
\text { outer rods are used for reactivity control and power shaping during power operation. } \\
\text { Fully inserted they can maintain the core in a Hot Zero Power condition. The rod is } \\
\text { subdivided into } 18 \text { separate capsules that allow enough flexibility to accommodate } \\
\text { any postulated offset between blocks, including seismically-induced shifting. } \\
\text { A second set of six rods can be inserted into the inner reflector blocks near the } \\
\text { core-reflector interface. These are fully withdrawn during power operation. Fully } \\
\text { inserting the outer and inner reflector CR can keep the core subcritical at low }\end{array}$ \\
\hline
\end{tabular}




\begin{tabular}{|c|c|}
\hline Criteria & Small Modular High Temperature Reactor (smHTR) \\
\hline & $\begin{array}{l}\text { temperatures. } \\
\text { A reserve shutdown system (RSS) provides independent shutdown reactivity under all } \\
\text { conditions. The RSS consists of natural boron particles embedded in a graphite matrix } \\
\text { that is formed into spheres. The } \mathrm{B}_{4} \mathrm{C} \text { granules may be coated with pyrolytic carbon to } \\
\text { limit oxidation and loss from the system during high temperature, high moisture } \\
\text { events. When released into the reserve shutdown channel in the RSC fuel elements, } \\
\text { the pellets have a packing fraction of } \geq 0.55 \text {. For the MHTGR, the weight percent of } \\
\text { boron in the spheres is } 40 \% \text { in the MHTGR. } \\
\text { In the HTR Modul PBR, there are six independently actuated CR containing } \mathrm{B}_{4} \mathrm{C} \text { that } \\
\text { can be inserted into the side (outer) reflector to maintain and shape power. These are } \\
\text { sufficient to hold the reactor at a Hot Zero Power condition. Another } 18 \text { channels in } \\
\text { the outer reflector can be filled with Coated } \mathrm{B}_{4} \mathrm{C} \text { spheres to maintain the core in a } \\
\text { subcritical state indefinitely at ambient conditions (RSS). } \\
\text { Decay Heat Removal: Active core cooling is not necessary for the adequate removal } \\
\text { of decay heat during an accident. Conduction and radiative heat transfer will remove } \\
\text { heat at a sufficient rate to prevent significant fission product migration out of the fuel } \\
\text { element. An unmitigated loss of forced cooling, however, can lead to excessive } \\
\text { temperatures in the metallic components (such as control rod assemblies) with } \\
\text { possible failure of those structures. In the absence of primary system cooling, the } \\
\text { RCCS draws off sufficient heat to prevent damage to the pressure vessel or } \\
\text { confinement building. Any available natural circulation of coolant in the primary will } \\
\text { decrease the thermal power that the RCCS must dissipate. } \\
\text { Inherent Safety Approach } \\
\text { The HTGR design requirements specify the HTGR design shall have passive means of } \\
\text { negative reactivity insertion and decay heat removal sufficient to place the reactor } \\
\text { system in a safe stable state for any anticipated transient events without significant } \\
\text { damage to the core or reactor system structure. }\end{array}$ \\
\hline $\begin{array}{l}\text { 3) Describe the expected response } \\
\text { of the ARC to normal and } \\
\text { abnormal conditions. } \\
\text { Demonstrate that the ARC } \\
\text { design and associated } \\
\text { instrumentation will provide } \\
\text { operators with longer times than } \\
\text { for current generation LWRs for } \\
\text { system diagnosis before reaching } \\
\text { safety systems challenge and/or } \\
\text { exposure of vital equipment to } \\
\text { adverse conditions. }\end{array}$ & $\begin{array}{l}\text { Due to the low power density and large thermal inertia of the mostly-graphite core, all } \\
\text { transients are characteristically slow compared to an LWR and none can result in fuel } \\
\text { failure. In the bounding (peak fuel temperature) case, the depressurized loss of forced } \\
\text { cooling resulting from a large break in the primary coolant boundary, the resulting } \\
\text { core temperature rise and negative temperature coefficient immediately halts the } \\
\text { fission reaction. Fission product decay causes the core temperature to increase over a } \\
\text { span of tens of hours before beginning a slow decline. If no control elements are } \\
\text { inserted, the core will go critical after a few days but at significantly reduced power } \\
\text { level (usually less than } 3 \mathrm{MW} \text { and corresponding to the maximum heat removal rate of } \\
\text { the RCCS). Eventually, the core will attain an equilibrium state in which the fission } \\
\text { power is balanced by the power radiated to the ultimate heat sink. At no time, does the } \\
\text { fuel temperature exceed the level at which significant (actionable) quantities of fission } \\
\text { products are released. Pressurized loss of forced coolant flow, while somewhat less } \\
\text { severe than a depressurized event, has been demonstrated numerous times in AVR, } \\
\text { HTTR, and HTR-10. } \\
\text { In the event of a large break in the primary, the reactor building is immediately vented } \\
\text { to the atmosphere to reduce the system pressure to ambient levels. (The circulating } \\
\text { activity is low enough such that worker and off-site does are well within acceptable } \\
\text { levels.) The vents are then closed for the heat-up stage of the transient. At low } \\
\text { pressure, any additional releases can be vented through filters. } \\
\text { Preliminary safety analysis indicate that the inherent neutronic, hydraulic, and thermal } \\
\text { performance characteristics of the HTGR design provide self-protection in } \\
\text { beyond-design- basis sequences involving combined earthquake and DLOFC events } \\
\text { to limit accident consequences without activation of engineered systems or operator } \\
\text { actions. }\end{array}$ \\
\hline $\begin{array}{l}\text { Describe the design features that } \\
\text { will reduce the probability for } \\
\text { accidents, including accidents } \\
\text { with potentially severe } \\
\text { consequences. These design } \\
\text { features should provide }\end{array}$ & $\begin{array}{l}\text { The primary tenet of the inherent safety approach of HTGR is to utilize design } \\
\text { features for prevention of core damage and related consequences, even for } \\
\text { beyond-design-basis events that involve the failure of multiple safety grade systems } \\
\text { The preliminary safety analysis shows that the inherent neutronic, hydraulic, and } \\
\text { thermal performance characteristics of the HTGR design provide self-protection to } \\
\text { limit accident consequences without activation of engineered systems or operator }\end{array}$ \\
\hline
\end{tabular}




\begin{tabular}{|c|c|}
\hline Criteria & Small Modular High Temperature Reactor (smHTR) \\
\hline \multirow{9}{*}{$\begin{array}{l}\text { sufficient reliability, redundancy, } \\
\text { diversity, and independence in } \\
\text { safety systems to provide for } \\
\text { either accident prevention or } \\
\text { accident mitigation. }\end{array}$} & $\begin{array}{l}\text { actions. Specifically, the HTGR has the following design and inherent features that } \\
\text { minimize the potential for severe accidents and their consequences: }\end{array}$ \\
\hline & $\begin{array}{l}\text { 1) Inherent characteristics of the reactor system: low power density, high thermal } \\
\text { inertia of the active core, chemically inert gas-phase coolant, total negative reactivity } \\
\text { coefficient; large temperature margin to fuel failure and robust fuel form }\end{array}$ \\
\hline & $\begin{array}{l}\text { 2) Passive shutdown heat removal system provides sufficient decay heat removal to } \\
\text { insure fuel integrity under all anticipated scenarios. }\end{array}$ \\
\hline & $\begin{array}{l}\text { 3) Containment function is provided by the multiple coatings of the fuel particle } \\
\text { which retain their radiological inventory under all anticipated loss of forced cooling } \\
\text { scenarios. The graphite matrix, primary coolant boundary, and reactor building also } \\
\text { serve to retain fission products in the event of the most severe events. }\end{array}$ \\
\hline & $\begin{array}{l}\text { 4) Chemically inert coolant and graphite are resistant to ingress of oxygen and water } \\
\text { in the primary system. Severe water or air ingress may result in the surface } \\
\text { degradation of some of the graphite structures (particularly the bottom reflector which } \\
\text { is at the highest temperature) if the rate of air ingress is maintained at a high level. } \\
\text { Bulk graphite does not burn but surface oxidation can occur under a narrow range of } \\
\text { conditions. Circulating graphite dust (present mainly in PBRs with moving fuel) may } \\
\text { transport small amounts of contamination which would be released in the event of a } \\
\text { pipe break. Graphite dust has a very low combustibility index (far lower than wheat } \\
\text { flour, for example). Partial oxidation of graphite may lead to the formation of carbon } \\
\text { monoxide (CO) which, if vented to the reactor building, may combine with oxygen } \\
\text { and burn under extreme scenarios. CO formation has not been observed in any } \\
\text { operating HTGR. }\end{array}$ \\
\hline & $\begin{array}{l}\text { Steam ingress may also result in the oxidation of graphite structures and the release of } \\
\text { small amounts of radioactive materials into the primary coolant. Both Fort St. Vrain } \\
\text { and AVR experienced large core flooding events but recovered fully with no } \\
\text { radiological consequences. }\end{array}$ \\
\hline & 5) At least two independent control rod/absorber sphere systems, as described above. \\
\hline & $\begin{array}{l}\text { 6) In contrast to LWR design, where a combined earthquake event followed by a loss } \\
\text { of forced cooling or off-site power would lead to significant distortions in the core } \\
\text { geometry and the partial uncovering of the fuel assemblies and possible cladding } \\
\text { failure, the same event in these HTGR designs would result in very small core } \\
\text { geometry changes (the prismatic blocks and pebbles are already packed tightly, with a } \\
\text { peak packing fraction increase from } 0.61 \text { to } 0.63 \text { expected in case of a severe } \\
\text { earthquake). The loss of the helium coolant (i.e. uncovered HTGR fuel) would also } \\
\text { not result in any particle failures. } \\
\text { In the extreme scenario of exposed HTGR fuel (blocks or pebbles) directly in contact } \\
\text { with the atmosphere in the aftermath of such an event, the graphite and TRISO layers } \\
\text { act as significant delay barriers to the chemical interaction with either water or } \\
\text { oxygen, in stark contrast to current LWR fuel cladding materials that are particularly } \\
\text { vulnerable to chemical attack and the production of hydrogen gas. }\end{array}$ \\
\hline & $\begin{array}{l}\text { 7) Reactivity insertion events in both these HTGR designs (via control rod } \\
\text { withdrawals or water ingress) are much less severe when compared to LWR designs, } \\
\text { due to the low power density and total excess reactivity available. This is especially } \\
\text { true for the online refueling schemes followed by the pebble bed designs. }\end{array}$ \\
\hline \multirow[t]{4}{*}{$\begin{array}{l}\text { 5) Describe the design features that } \\
\text { will minimize potential radiation } \\
\text { exposures to plant personnel. }\end{array}$} & $\begin{array}{l}\text { Radiological exposures are expected to be much lower than those of conventional } \\
\text { LWR systems. The total exposure estimate for the MHTGR, as reported to the NRC in } \\
\text { DOE-HTGR-86-024, is } 149 \text { person-rem which includes a } 20 \% \text { contingency to account } \\
\text { for uncertainties. For a } 4 \text { module plant assuming } 80 \% \text { availability and estimated } \\
\text { staffing levels(1986 assumptions), this translates into } 0.38 \text { person-rem/MWe-year or } \\
\text { just over } 208 \text { person-rem annual dose, a factor of } 4-7 \text { lower than an comparable LWR } \\
\text { in its day. Through 1983, Fort St. Vrain averaged } 0.04 \text { person-rem/MWe-year. Peach } \\
\text { Bottom-1 averaged } 0.12 \text { person-rem/MWe-year in its last three years of operation [9]. }\end{array}$ \\
\hline & No worker dose data were available for the HTR Modul. \\
\hline & $\begin{array}{l}\text { The superior performance observed in recent NGNP/AGR fuel irradiation and safety } \\
\text { tests, should yield considerably lower doses for an smHTR built today. }\end{array}$ \\
\hline & The low doses of the HTGR are attributed to the superior retention qualities of the \\
\hline
\end{tabular}




\begin{tabular}{|c|c|}
\hline Criteria & Small Modular High Temperature Reactor (smHTR) \\
\hline & $\begin{array}{l}\text { TRISO fuel, graphite matrix, and inert coolant chemistry. A plant built today can also } \\
\text { exploit remote technologies and repair features to further reduce exposure. }\end{array}$ \\
\hline $\begin{array}{l}\text { 6) Describe how incorporation of } \\
\text { defense-in-depth philosophy is } \\
\text { accomplished in the ARC } \\
\text { design. Specifically, describe } \\
\text { how the multiple barriers are } \\
\text { maintained to prevent radiation } \\
\text { release, and thereby reduce the } \\
\text { potential for, and consequences } \\
\text { of, severe accidents. }\end{array}$ & $\begin{array}{l}\text { The HTGR defense in depth approach is outlined in [10]. } \\
\text { The principles of defense-in-depth are applied in the design, construction, and } \\
\text { operation of existing and advanced nuclear power plants; the NGNP design is no } \\
\text { exception. In the design and analysis process for the NGNP HTGR, the "historic" } \\
\text { deterministic approach is integrated with a risk-informed performance-based } \\
\text { evaluation methodology to ensure that selected design features provide the required } \\
\text { level of safety and defense-in-depth. The result is a set of conservative design features } \\
\text { combined with inherent reactor characteristics, passive design features, and active } \\
\text { systems to (1) prevent transients and accidents, (2) ensure the performance of safety } \\
\text { functions, (3) prevent the release of radioactive material, and (4) mitigate the } \\
\text { consequences of accidents. The principles of multiple, independent, and concentric } \\
\text { barriers to radionuclide transport and release are assessed for each significant source } \\
\text { of radioactive material to assure that defense-in-depth has been maintained. In } \\
\text { addition, the principles of design margin, redundancy, and diversity are applied in the } \\
\text { design of the SSCs that support the required safety functions and serve to support and } \\
\text { maintain the integrity and effectiveness of these barriers. The defense-in-depth } \\
\text { strategies ensure that TLRC are met, adequate safety margins are achieved, } \\
\text { deterministic principles of defense-in-depth are applied, and uncertainties in the } \\
\text { reliabilities and capabilities of the SSCs providing the required safety functions are } \\
\text { adequately addressed over the life of the plant. } \\
\text { The five barriers to radionuclide release that form a functional containment system for } \\
\text { modular HTGRs are as follows: } \\
\text { 1. The fuel particle kernel, } \\
\text { 2. The fuel particle coatings (silicon carbide and pyrocarbon coatings), } \\
\text { 3. The core graphite and carbonaceous materials, } \\
\text { 4. The helium pressure boundary, and } \\
\text { 5. The reactor building. } \\
\text { These barriers are described in detail in [10]. }\end{array}$ \\
\hline $\begin{array}{l}\text { 7) State how safety and security } \\
\text { requirements will be considered } \\
\text { together in the design process } \\
\text { such that security issues (e.g., } \\
\text { newly identified threats of } \\
\text { terrorist attacks) can be } \\
\text { effectively resolved through } \\
\text { facility design and engineered } \\
\text { security features, and } \\
\text { formulation of mitigation } \\
\text { measures, with reduced reliance } \\
\text { on human actions. }\end{array}$ & $\begin{array}{l}\text { The HTGR design requirements specify that the reactor shall be designed to minimize } \\
\text { the risk of sabotage or proliferation, either through design features, or by proven } \\
\text { safeguards and security techniques, or a combination of the two. Security is } \\
\text { integrated into the design process. } \\
\text { 1) The reactor module is located below grade in a silo structure that is hardened and } \\
\text { provides a low profile. } \\
\text { 2) The inherent safety features of the HTGR offer a high level of protection against } \\
\text { malevolent events, as well as against accidents. } \\
\text { 3) Core replacement is done remotely using in-vessel transfer systems and ex-vessel } \\
\text { shielded casks in the case of the MHTGR. In the case of the HTR Modul, all fuel } \\
\text { handling operations are performed remotely and automatically. }\end{array}$ \\
\hline $\begin{array}{l}\text { 8) Describe the features that could } \\
\text { result in a large release of } \\
\text { radioactive materials, such as } \\
\text { those that would prevent a } \\
\text { simultaneous loss of containment } \\
\text { integrity (including situations } \\
\text { where the containment is by- } \\
\text { passed), and the ability to } \\
\text { maintain core cooling as a result } \\
\text { of an aircraft impact. If } \\
\text { prevention of release is not } \\
\text { possible under this scenario, } \\
\text { identify system designs that } \\
\text { would provide a delay in } \\
\text { radiological releases to facilitate } \\
\text { any required emergency }\end{array}$ & $\begin{array}{l}\text { The MHTGR and HTR Modul design efforts did not include assessments of aircraft } \\
\text { impact. } \\
\text { The location of the reactor vessel and primary components below grade greatly } \\
\text { decrease the probability of an impact. }\end{array}$ \\
\hline
\end{tabular}




\begin{tabular}{|c|c|}
\hline Criteria & Small Modular High Temperature Reactor (smHTR) \\
\hline $\begin{array}{l}\text { response both on-site and off- } \\
\text { site. }\end{array}$ & \\
\hline $\begin{array}{l}\text { 9) Describe the features that will } \\
\text { prevent loss of onsite spent fuel } \\
\text { storage facility integrity (if part } \\
\text { of the ARC design), including } \\
\text { consideration of an aircraft } \\
\text { impact. }\end{array}$ & $\begin{array}{l}\text { In the original designs, fuel elements discharged from either the MHTGR or HTR } \\
\text { Modul core would be stored in water cooled storage pools for up to a year. These } \\
\text { pools would be inside the reactor building which is resilient against impact. Beyond } 1 \\
\text { year, the elements would be transferred to air-cooled storage containers which are } \\
\text { much less vulnerable to failure due to impact. The failure of either the water or air } \\
\text { spent fuel cooling facilities would not impact the low power density HTGR fuel form } \\
\text { significantly as passive heat removal by conduction and radiation would be sufficient } \\
\text { to prevent a large fraction of the more than } 1 \text { billion TRISO fuel particles in typical } \\
\text { HTGR core to reach temperatures in excess of } 1800^{\circ} \mathrm{C} \text {. Recent discussions with } \\
\text { vendors indicvate that the short-term water-cooled storage could be replaced by a } \\
\text { completely passive, air-cooled system. }\end{array}$ \\
\hline $\begin{array}{l}\text { 10) Identify any R\&D that would be } \\
\text { needed to bring any of the } \\
\text { safety-related technologies used } \\
\text { in the design to a sufficient level } \\
\text { of maturity to allow for } \\
\text { industrial use. }\end{array}$ & $\begin{array}{l}\text { Complete the AGR Fuel and AGC graphite Qualifications programs and Inconel } 617 \\
\text { for higher temperatures.. Details can be found in [1]. }\end{array}$ \\
\hline \multicolumn{2}{|l|}{ Category II. Security } \\
\hline $\begin{array}{l}\text { 1) Types of special nuclear } \\
\text { materials (SNM) present and the } \\
\text { security features that provide } \\
\text { SNM protection. }\end{array}$ & 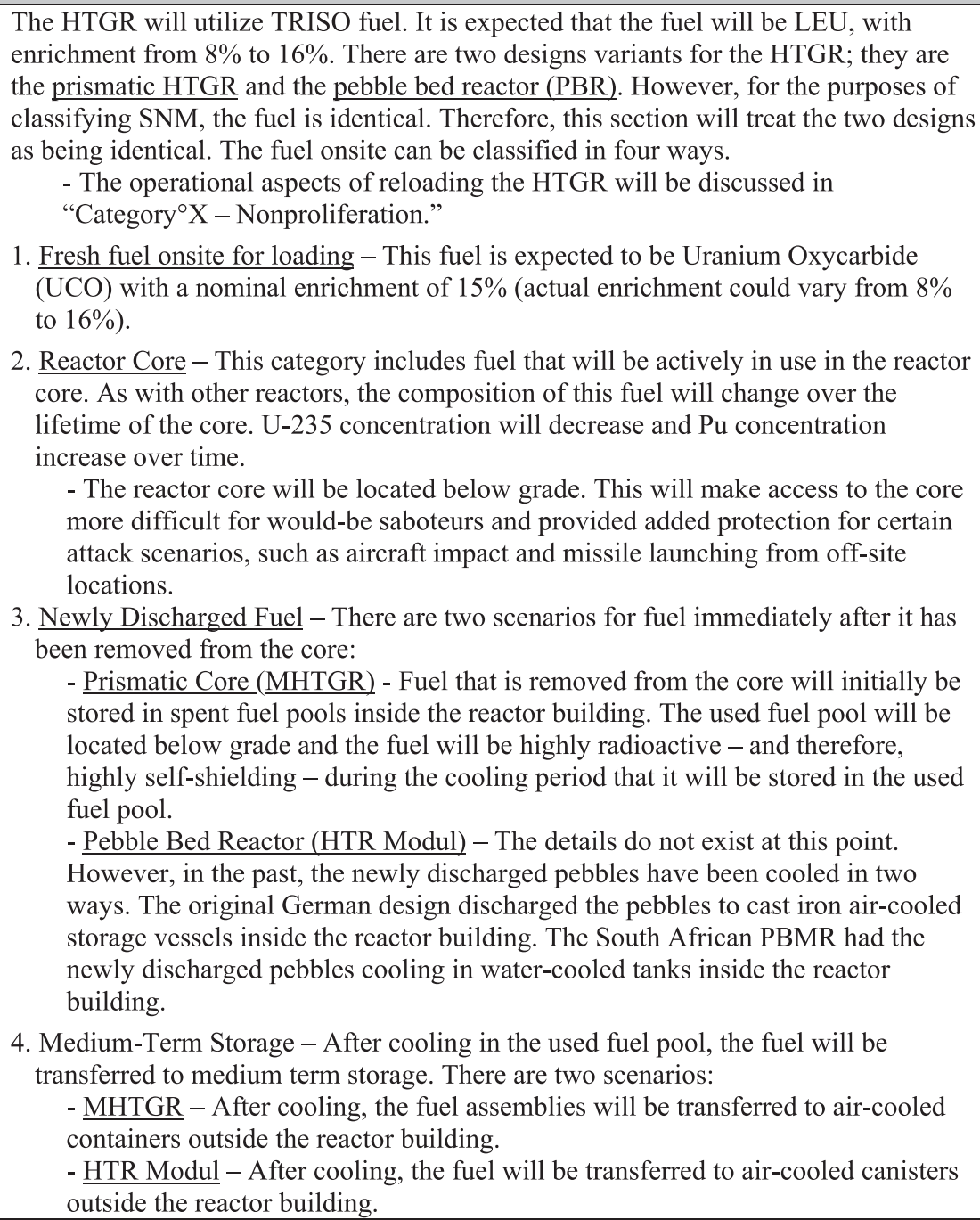 \\
\hline $\begin{array}{l}\text { 2) Consideration of security } \\
\text { requirements together }\end{array}$ & $\begin{array}{l}\text { The HTGR is in an early stage of engineering development. As such, no explicit } \\
\text { Physical Protection System (PPS) has been designed. }\end{array}$ \\
\hline
\end{tabular}




\begin{tabular}{|c|c|}
\hline Criteria & Small Modular High Temperature Reactor (smHTR) \\
\hline $\begin{array}{l}\text { throughout the design process so } \\
\text { that security issues (e.g., threats } \\
\text { of theft, diversion, and sabotage) } \\
\text { can be effectively anticipated, } \\
\text { identified, and addressed at an } \\
\text { early stage through integrated } \\
\text { facility design and engineered } \\
\text { security features, and through } \\
\text { formulation of } \\
\text { response/mitigation measures, } \\
\text { ideally with reduced reliance on } \\
\text { human actions compared with } \\
\text { previous generations. }\end{array}$ & $\begin{array}{l}\text { However, it is expected that security experts will be made an integral part of the } \\
\text { design/engineering team to ensure that Security By Design is implemented throughout } \\
\text { the process in the future. Theft and sabotage scenarios will be considered. Regulatory } \\
\text { requirements will be met or exceeded. Hardening of components and systems against } \\
\text { both theft and sabotage will be accomplished via a process of interacting with safety } \\
\text { systems designers. All aspects of plant design and operation will be considered during } \\
\text { the development of the PPS. Cost-Benefit Analysis for design improvements will be } \\
\text { included in any scenario analysis. Mitigation of the effects of any potential security } \\
\text { events will be considered as part of the PPS design process. } \\
\text { Diversion possibilities will be minimized via the use of a transparency process that } \\
\text { will ensure regulators have up-to-date information. Information from operations, } \\
\text { safety, and security will be shared with safeguards personnel and with the appropriate } \\
\text { regulatory authorities to ensure that, overall, a transparent system is in place. }\end{array}$ \\
\hline $\begin{array}{l}\text { 3) Features to prevent/mitigate } \\
\text { sabotage threats, e.g., loss of } \\
\text { integrity of onsite core fuel and } \\
\text { spent fuel storage, including } \\
\text { consideration of an aircraft } \\
\text { impact and other relevant attack } \\
\text { scenarios. }\end{array}$ & $\begin{array}{l}\text { Both the reactor and the short-term storage are located underground, which makes } \\
\text { access to the fuel difficult to achieve. In current designs, the fuel will be placed in } \\
\text { above-ground canisters for medium-term storage. The plan is to keep the fuel in these } \\
\text { canisters until such time this fuel can be shipped off-site to be placed in long-term } \\
\text { storage. It may be prudent to revisit the used fuel storage scheme over the course of } \\
\text { developing the plant/site design in order to make it easier to provide security at a } \\
\text { lower cost. For example, providing a means of storing the used fuel underground for } \\
\text { an extended period may decrease the need for armed security personnel. } \\
\text { Other aspects of the PPS will be developed throughout the design process of the plant } \\
\text { and will include security experts to ensure the protection of any onsite fuel. }\end{array}$ \\
\hline $\begin{array}{l}\text { 4) Features to eliminate or reduce } \\
\text { the potential theft of nuclear } \\
\text { material. }\end{array}$ & $\begin{array}{l}\text { Both the reactor and the short-term storage are located underground, which makes } \\
\text { access to the fuel difficult to achieve. In current designs, the fuel will be placed in } \\
\text { above-ground canisters for medium-term storage. The plan is to keep the fuel in these } \\
\text { canisters until such time this fuel can be shipped off-site to be placed in long-term } \\
\text { storage. It may be prudent to revisit the used fuel storage scheme over the course of } \\
\text { developing the plant/site design in order to make it easier to provide security at a } \\
\text { lower cost. For example, providing a means of storing the used fuel underground for } \\
\text { an extended period may decrease the need for armed security personnel. } \\
\text { The high volume fraction of graphite in the fuel elements requires the conspicuous } \\
\text { movement of large amounts of material relative to the amount of special nuclear } \\
\text { material contained within. } \\
\text { Other aspects of the PPS will be developed throughout the design process of the plant } \\
\text { and will include security experts to ensure the protection of any onsite fuel. }\end{array}$ \\
\hline $\begin{array}{l}\text { 5) Any features that will require } \\
\text { R\&D to bring to maturity. }\end{array}$ & $\begin{array}{l}\text { Conventional LWRs become more vulnerable during refueling. Thus, it is common } \\
\text { for security experts to assess the refueling procedures for any reactor design. } \\
\text { The MHTGR is expected to need refueling every } 18-20 \text { months, at which time the fuel } \\
\text { blocks will be replaced. However, the fuel handling procedures that have been } \\
\text { outlined for this design were developed about } 30 \text { years ago; these procedures will } \\
\text { probably need to be updated. If so, it would be prudent to engage security } \\
\text { professionals in the design process. In this way, the PPS can be developed in harmony } \\
\text { with the safety and operational procedures that are required for refueling, thereby } \\
\text { avoiding potentially costly security personnel and retrofitting of the plant. } \\
\text { The HTR Modul will employ an online refueling methodology. With } 15 \% \text { enriched } \\
\text { fuel, about } 175 \text { pebbles will be added to the core daily. This process will need to be } \\
\text { closely monitored to ensure that theft of the material is not an issue, especially to } \\
\text { guard against the insider threat that could exist. } \\
\text { The use of SBD to aid in developing these fuel handling procedures and to ensure that } \\
\text { these operations do not cause undue stress on other operational aspects of the plant } \\
\text { would seem to be a necessary step. }\end{array}$ \\
\hline \multicolumn{2}{|c|}{$\begin{array}{l}\text { Category III. Compatibility of the concept with traditional and advanced energy conversion systems/processes, maximizing } \\
\text { energy production per fuel quantity used }\end{array}$} \\
\hline $\begin{array}{l}\text { 1) Compatibility between the } \\
\text { pressure, temperature, and } \\
\text { chemistry of the ARC coolant } \\
\text { and the fluid properties in the }\end{array}$ & $\begin{array}{l}\text { Helium is inert and thus wholly compatible with the materials used in the primary } \\
\text { system. Recent research indicates that a small amount of oxygen (a few ppm) is } \\
\text { needed to retain a oxide layer on some metallic components to protect against certain } \\
\text { types of degradation. The primary loop operates at around } 7 \text { MPA, comparable to a }\end{array}$ \\
\hline
\end{tabular}




\begin{tabular}{|c|c|}
\hline Criteria & Small Modular High Temperature Reactor (smHTR) \\
\hline energy conversion system. & $\begin{array}{l}\text { Boiling Water Reactor (BWR), and thus the pressure drops across the steam generator } \\
\text { tubes are not excessive. Alloy } 800 \mathrm{H} \text { is currently code qualified for } 300,000 \text { hours } \\
\text { (supporting } 40 \text {-year plant life) and up to } 760^{\circ} \mathrm{C} \text { in the nuclear section of the ASME } \\
\text { Boiler and Pressure Vessel Code. Additional qualification is planned which would } \\
\text { extend the ASME code for plant lives up to } 60 \text { years. An ASME Code Case for } \\
\text { Alloy } 617 \text { is being developed for temperatures up to } 950^{\circ} \mathrm{C} \text { and lifetimes up to } \\
100,000 \text { hours. The HTTR in Japan operates with a } 950^{\circ} \mathrm{C} \text { outlet temperature and } 10 \text { - } \\
\text { year design lifetime, as did the AVR. At the very high temperature of } 950^{\circ} \mathrm{C} \text {, } \\
\text { structural components constructed from Alloy } 617 \text { would have to be designed as } \\
\text { replaceable components for a } 40 \text {-year or a } 60 \text {-year plant design life. }\end{array}$ \\
\hline $\begin{array}{l}\text { 2) Address whether off-the-shelf } \\
\text { commercially available or newly } \\
\text { developed energy conversion } \\
\text { equipment (e.g. compressors, } \\
\text { turbines, seals, bearings, printed } \\
\text { circuit heat exchangers, etc.) can } \\
\text { be used, or would it be necessary } \\
\text { to develop new energy } \\
\text { conversion machinery and } \\
\text { equipment to satisfy the } \\
\text { conditions proposed for the } \\
\text { ARC? }\end{array}$ & $\begin{array}{l}\text { Steam Rankine cycle power conversion technology is well developed and the system } \\
\text { components are largely off-the-shelf items available from commercial vendors. } \\
\text { For printed circuit heat exchangers, structural integrity of diffusion bonds, post- } \\
\text { construction examination and in-service inspection, and ASME code stamping are the } \\
\text { challenges that need to be overcome in order to allow it to be part of the nuclear } \\
\text { boundary. }\end{array}$ \\
\hline $\begin{array}{l}\text { 3) Availability of proven materials } \\
\text { for anticipated primary and } \\
\text { secondary system pressures and } \\
\text { temperatures. }\end{array}$ & 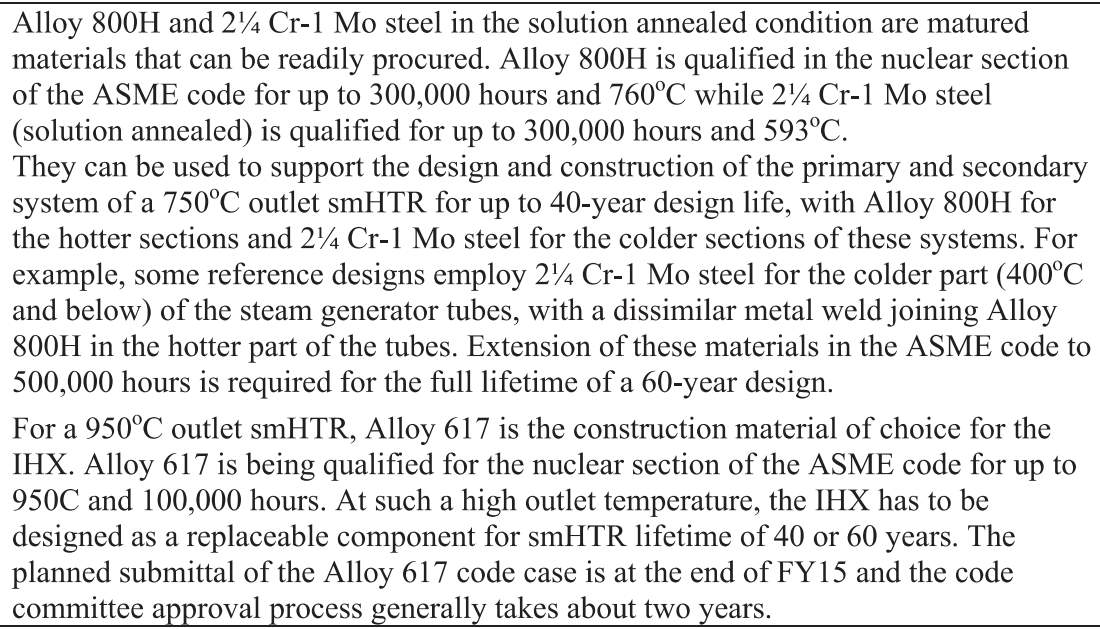 \\
\hline $\begin{array}{l}\text { 4) The potential susceptibility of } \\
\text { the conversion system to } \\
\text { traditional conversion system } \\
\text { challenges, e.g., plugging, } \\
\text { corrosion, etc. }\end{array}$ & $\begin{array}{l}\text { Steam system: Ferritic steels are typically used in the steam generator. High purity } \\
\text { feedwater is required to prevent deposition of impurities on heat transfer surfaces and } \\
\text { to preclude intergranular stress-corrosion cracking of the heat transfer surfaces. This } \\
\text { requires careful attention to the design and material selection for each component of } \\
\text { the system, i.e., on-line water monitoring, full flow filters, full-flow demineralizers, } \\
\text { and pH control. } \\
\text { Graphite dust is known to build up in PBRs, mainly from abrasion of pebbles inside } \\
\text { the fuel handling system. An AVR, dust accumulation on some of the colder parts of } \\
\text { the coolant piping was observed after decommissioning but was not an operational } \\
\text { issue. This may be an issue for the HTR Modul if compact heat exchangers are used to } \\
\text { drive a Brayton cycle power conversion system Dust in the primary circuit has not } \\
\text { been observed in significant quantities in prismatic reactors like the MHTGR. }\end{array}$ \\
\hline $\begin{array}{l}\text { 5) If steam conversion systems are } \\
\text { proposed, the compatibility of } \\
\text { the ARC coolant with the } \\
\text { traditional Rankine energy } \\
\text { conversion cycle, in terms of } \\
\text { fluid properties, pressure, } \\
\text { temperature, chemistry and } \\
\text { limits imposed on materials used }\end{array}$ & $\begin{array}{l}\text { All HTGRs operated to date have driven Rankine cycle systems. The two reference } \\
\text { systems were designed for the Rankine cycle. As discussed in criterion II.3 above, } \\
\text { Alloy } 800 \mathrm{H} \text { will allow extended steam generator operation for up to } 40 \text { years and at } \\
\text { temperatures up to } 760^{\circ} \mathrm{C} \text {. For longer lifetimes, extension of Alloy } 800 \mathrm{H} \text { in the ASME } \\
\text { code beyond } 300,000 \text { hours is required. Similar extension is required if } 2 \frac{1}{4} \mathrm{Cr}-1 \mathrm{Mo} \\
\text { steel in the solution annealed condition is used in the colder section of the steam } \\
\text { generator tubes. }\end{array}$ \\
\hline
\end{tabular}




\begin{tabular}{|c|c|}
\hline Criteria & Small Modular High Temperature Reactor (smHTR) \\
\hline in energy conversion systems. & \\
\hline \multicolumn{2}{|c|}{ Category III. Ability to improve uranium resource utilization and minimize waste generation } \\
\hline
\end{tabular}

\begin{tabular}{l|l}
\hline 1) Uranium resource utilization. & $\begin{array}{l}\text { The HTGR is configured for high outlet temperature and passive safety, not actinide } \\
\text { management. }\end{array}$ \\
\hline
\end{tabular}

a) Uranium enrichment required $\quad$ The reference concepts are designed to run on LEU but at a higher enrichment than (compared to existing LWR LWRs. The fuel being qualified with ARC-VHTR is enriched to about $15 \%$. systems).

b) Design features, if any, that reduce uranium consumption.

c) Is the use of reprocessed fuel planned for the ARC system in its fuel cycle?

The HTR Modul pebble bed core recirculates fuel to achieve maximum burnup for a given enrichment.

d) What is the expected conversion ratio for the proposed ARC design? Can the ARC system be used for fissile material breeding?

e) What are the $R \& D$ needs?

2) Estimate of waste generation (qualitatively compared to a once-through LWR).

Spent LWR fuel can be cast into TRISO particles for additional plutonium incineration (Deep Burn) but this is not envisioned for the reference concepts. The TRISO fuel form can be used to achieve high burnup.

$\mathrm{CR}<70 \%$. Peach Bottom-1, Fort St. Vrain, and THTR all ran on a fissile-fertile mixture of thorium and highly enriched uranium to achieve high conversion ratios but this is not envisioned for the reference smHTGRs.

a) Ability to transmute long-lived products in nuclear waste: those produced in situ during reactor operation.

b) Mass of discharged materials

c) Mass (qualitatively compared to an LWR discharge) of low heat, long-lived materials (examples Carbon 14, Technetium 99, Iodine 129).

d) Mass (qualitatively compared to an LWR discharge) of low heat, low longevity materials (Class A, B, C low-level waste (LLW).

e) $R \& D$ needs to facilitate transmutation or other waste management goals.

While some concepts have been demonstrated at lab scale, tf reprocessing is pursued, some development of fuel disassembly technology at larger scale may be required.

The HTGR is a thermal spectrum reactor running on LEU so actinide buildup will be comparable to an LWR. The HTGR spectrum is suitable for plutonium incineration in a so-called Deep Burn configuration but higher actinides will continue to accumulate.

The substantially higher burnup achievable in TRISO fuel allows greater energy production from an equivalent input of heavy metal in an LWR.

Spent fuel characteristics of the HTGR will not be significantly different from the LWR of comparable burnup.

The MHTGR running on AGR fuel achieves a burnup of about $100 \mathrm{MWD} / \mathrm{kg}$. The HTR Modul recirculates the fuel and thus each pebble stays in the core until the target burnup level is reached, which for AGR fuel is about $160 \mathrm{MWD} / \mathrm{kg}$. Online refueling also allows for a higher capacity factor $(>90 \%)$.

C-14 discharges will be considerable higher than an LWR due to the buildup in the graphite(from transmutation of nitrogen in impurities). Fission products will be somewhat lower on a per MWD basis because of the higher efficiency and burnup.

Discharge of low heat materials will be considerable higher than an LWR due to the large volume of graphite.

Category IV. Operational capabilities and aspects such as control strategies, operating modes (e.g., base load versus load following capability), maintenance and inspection requirements, refueling interval, etc.

1) Flexibility in electricity generation including the proposed ARC capability for load following (the capability to adjust generation as demand for electricity fluctuates).

Limitations, if any, on such operation arising from considerations of fuel performance, reactivity limitations, mechanical and

The large thermal inertia of the smHTGR core that provides confers many safety benefits also precludes rapid (on the order of minutes) response to changes in load. Slower fluctuations in demand can be accommodated. Many smHTGR concepts are designed to produce multiple energy products (electricity, process heat, hydrogen, etc.) which may allow for rapid shifting between parallel loads.

An OECD transient benchmark project focused on the PBMR-400 (MWt) modular design specified a $100 \%-40 \%-100 \%$ load follow operation with the power-down and power-up ramps each occurring over a 6-minute interval. A similar project for the MHTGR specifies a $\% 100-\% 50$ power ramp occurring over 5 minutes to stimulate a xenon oscillation.

In the $15 \%$ to $100 \%$ power range, power output is adjusted by varying the position of 


\begin{tabular}{|c|c|}
\hline Criteria & Small Modular High Temperature Reactor (smHTR) \\
\hline $\begin{array}{l}\text { thermal stress in materials and } \\
\text { components should be } \\
\text { addressed. }\end{array}$ & $\begin{array}{l}\text { the helium bypass valves over the short term ( } 0 \text { to } 20 \mathrm{~min}) \text { and by varying helium } \\
\text { inventory over the long term ( } 0 \text { to } 60 \mathrm{~min}) \text {. Temperature is maintained constant } \\
\text { throughout these operations due to the inherent effects of the negative temperature } \\
\text { coefficient of reactivity and by small adjustments of the control rod position. } \\
\text { The systems, structures, and components in each of the reference concepts are } \\
\text { designed for such operation. }\end{array}$ \\
\hline $\begin{array}{l}\text { 2) Other features allowing } \\
\text { utilization beyond base-load } \\
\text { electricity production, for } \\
\text { example process heat generation, } \\
\text { high temperature operation for } \\
\text { hydrogen production via } \\
\text { chemical splitting, etc. }\end{array}$ & $\begin{array}{l}\text { Both of the reference concepts are well-suited for applications 'beyond the grid'. The } \\
\text { high outlet temperature is uniquely suited to driving a number of process applications } \\
\text { such as hydrogen production (chemical or electrolytic), steam reformation of methane, } \\
\text { and coal-to-liquids conversion. The extremely low fission product release rate is } \\
\text { amenable to collocation of the process heat facility; the facility is close enough for } \\
\text { efficient heat transport but still outside of the emergency planning zone. }\end{array}$ \\
\hline $\begin{array}{l}\text { 3) Features expected to improve } \\
\text { availability in operation as } \\
\text { estimated from the system's } \\
\text { capacity factor, frequency of } \\
\text { outages for refueling, and other } \\
\text { planned outages (compared with } \\
\text { those for an LWR). Include in } \\
\text { the analysis of operational } \\
\text { availability/dependability, } \\
\text { elements from the information } \\
\text { requested under Category V that } \\
\text { follows, which includes concept } \\
\text { maturity and operating } \\
\text { experience (if available) } \\
\text { associated with the proposed } \\
\text { ARC. }\end{array}$ & $\begin{array}{l}\text { The } 80 \% \text { capacity factor quoted for the MHTGR is based upon the industry average in } \\
\text { the } 1980 \text { 's when the design was submitted to the NRC. Modern operational } \\
\text { procedures and operating experience are likely to increase availability. Refueling and } \\
\text { maintenance operations are not considerably different than an LWR. } \\
\text { The HTR Modul features online refueling and thus only needs to be shut down for } \\
\text { maintenance and repairs. Capacity factors well above } 90 \% \text { would be attainable. }\end{array}$ \\
\hline $\begin{array}{l}\text { 4) Maintenance and operation - Are } \\
\text { there features that will allow } \\
\text { easier maintenance to reduce the } \\
\text { duration and frequency of } \\
\text { outages? } \\
\text { Are there special requirements } \\
\text { for maintenance and inspection } \\
\text { that are different from current } \\
\text { LWRs (simpler or more } \\
\text { complex)? }\end{array}$ & $\begin{array}{l}\text { Helium is transparent and would allow for in-service inspection using remotely } \\
\text { operated instruments. } \\
\text { Requirements would be similar to those of LWRs. The relatively low fission product } \\
\text { release rates, however, will likely result in reduced worker does during such } \\
\text { operations. }\end{array}$ \\
\hline $\begin{array}{l}\text { 5) Describe design efforts to } \\
\text { provide reliable equipment in the } \\
\text { BOP (or safety-system } \\
\text { independence from BOP) to } \\
\text { reduce the number of challenges } \\
\text { to safety systems. }\end{array}$ & $\begin{array}{l}\text { Some small HTGR concepts have been designed with an intermediate gas cooling } \\
\text { loop as an additional buffer between process and the reactor but this choice is mainly } \\
\text { one of economics. Dynamically, the reactor core is loosely coupled to the secondary } \\
\text { and thus a severe BOP transient has minimal effect on core safety. } \\
\text { With a Rankine cycle, reliability is expected to follow LWR practice although no } \\
\text { specific reliability studies are cited. }\end{array}$ \\
\hline \multicolumn{2}{|c|}{$\begin{array}{l}\text { Category V. Concept maturity, operating experience, unknowns and assumptions (e.g., availability of advanced materials, } \\
\text { fuels, etc. currently under development). }\end{array}$} \\
\hline $\begin{array}{l}\text { 1) Description of the general level } \\
\text { of ARC design maturity } \\
\text { (pre-conceptual, conceptual, or } \\
\text { detailed). Identify the proposed } \\
\text { schedule for completion and } \\
\text { initial operation of the proposed } \\
\text { ARC. }\end{array}$ & $\begin{array}{l}\text { Both the MHTGR and HTR Modul designs are in the preliminary design stage. } \\
\text { Specific systems are based upon decades of technological maturity and experience. }\end{array}$ \\
\hline $\begin{array}{l}\text { 2) Description of Technology } \\
\text { Readiness Levels (based on } \\
\text { DOE TRL definition in DOE G }\end{array}$ & See the discussion on Technical Readiness in the previous section. \\
\hline
\end{tabular}




\begin{tabular}{|c|c|c|}
\hline & Criteria & Small Modular High Temperature Reactor (smHTR) \\
\hline & $\begin{array}{l}\text { 413.3-4, U.S. Department of } \\
\text { Energy Technology Readiness } \\
\text { Assessment Guide) of major } \\
\text { technologies and systems and } \\
\text { their relation to previous } \\
\text { operating reactors. Identify the } \\
\text { overall TRL of the proposed } \\
\text { ARC, which should be based on } \\
\text { the TRL of the least ready major } \\
\text { technology or system. }\end{array}$ & \\
\hline & $\begin{array}{l}\text { Applicable experience from } \\
\text { other reactor systems (test, } \\
\text { research, demonstration reactors, } \\
\text { naval reactors, foreign reactors) } \\
\text { such as design elements, } \\
\text { component testing and } \\
\text { demonstration). }\end{array}$ & $\begin{array}{l}\text { The lessons learned from high temperature reactor programs in the U.S. and } \\
\text { worldwide and the operating experience of seven demonstration and commercial } \\
\text { reactors have been incorporated into the design of the smHTR to the extent possible. } \\
\text { International collaboration under Gen IV International Forum, and bi-lateral } \\
\text { agreements has enhanced the transfer of HTGR/VHTR fuel and material technologies. }\end{array}$ \\
\hline & $\begin{array}{l}\text { Status of applicable design and } \\
\text { analysis tools. }\end{array}$ & $\begin{array}{l}\text { Codes developed for the } 1^{\text {st }} \text { generation HTGR programs (MICROX/DIF3D for } \\
\text { prismatic reactors and VSOP for PBRs) are available but are being supplanted by } \\
\text { modern tools including high fidelity neutron transport and computational fluid } \\
\text { dynamics (CFD). Although the old codes were used successfully to license the old } \\
\text { plants and the newer codes show great promise in terms of accuracy and resolution, } \\
\text { any code used for licensing an smHTGR will require formal validation and } \\
\text { verification. }\end{array}$ \\
\hline & $\begin{array}{l}\text { Discussion of the assumptions } \\
\text { made regarding the expected } \\
\text { ARC performance (associated } \\
\text { with unique or unproven aspects } \\
\text { of the design) and the basis of } \\
\text { those assumptions, including } \\
\text { identification of uncertainties. }\end{array}$ & $\begin{array}{l}\text { Design features of the MHTGR and HTR Modul were chosen originally based upon } \\
\text { tradeoff studies and analyses by the vendors, often in conjunction with national } \\
\text { laboratories in the US and Germany and greatly influenced by the operating } \\
\text { experiences of the early demonstration and commercial plants. } \\
\text { The latest releases of "industry standard" codes like RELAP-5 and SCALE have } \\
\text { already been modified to incorporate features that are unique to HTGR designs } \\
\text { (double heterogeneity, helium and graphite material properties, etc.). }\end{array}$ \\
\hline & $\begin{array}{l}\text { Identification of major } \\
\text { technology issues, R\&D needs to } \\
\text { address design and operational } \\
\text { uncertainties, and technology } \\
\text { gaps. }\end{array}$ & $\begin{array}{l}\text { Design Data Needs, issued in reports by the vendors, and reconciled with NGNP } \\
\text { research and development objectives were commissioned by the NGNP Project. }\end{array}$ \\
\hline 7) & $\begin{array}{l}\text { Estimated time frame to develop } \\
\text { the needed information identified } \\
\text { in Item } 6 \text { above. }\end{array}$ & $\begin{array}{l}\text { The remaining R\&D efforts could be completed in the decade required to build an } \\
\text { initial smHTGR plant. }\end{array}$ \\
\hline \multicolumn{3}{|c|}{ Category VI. Fuel Cycle Considerations } \\
\hline & $\begin{array}{l}\text { Ore mining and conversion } \\
\text { requirements (qualitatively } \\
\text { compared to the once-through } \\
\text { LWR cycle). }\end{array}$ & $\begin{array}{l}\text { Comparable. The smHTGR requires a higher enrichment than an LWR but also } \\
\text { achieves a higher burnup of the fuel, particularly the recirculating pebble bed version. }\end{array}$ \\
\hline & $\begin{array}{l}\text { Fuel fabrication (compared with } \\
\text { LWR fuel). }\end{array}$ & $\begin{array}{l}\text { Fuel fabrication is somewhat more complicated than an LWR. A sol-gel process is } \\
\text { used to manufacture the UCO kernels followed by a multistep particle coating } \\
\text { deposition process and compaction in a graphite matrix. Although TRISO-based fuel } \\
\text { was manufactured for the } 1^{\text {st }} \text { generation plants, production-scale capability in the US } \\
\text { was lost. Under the NGNP, a fuel vendor (B\&W) participated in the development and } \\
\text { qualification of a new fabrication technique. }\end{array}$ \\
\hline 3) & $\begin{array}{l}\text { Fuel form experience base (as } \\
\text { needed for licensing/ } \\
\text { certification) for fuel forms } \\
\text { different from current UO2 fuels. }\end{array}$ & $\begin{array}{l}\text { High quality } \mathrm{UO}_{2} \text { and UCO TRISO fuel was manufactured for the German HTGR } \\
\text { program and, with somewhat less success, for the early US program. Data from those } \\
\text { efforts is still marginally useful today but the licensing of a new reactor will rely } \\
\text { heavily on the testing that began in } 2004 \text { under the AGR (NGNP) program. }\end{array}$ \\
\hline & $\begin{array}{l}\text { Are the systems currently used } \\
\text { for managing used fuel/ waste in } \\
\text { LWRs applicable? }\end{array}$ & $\begin{array}{l}\text { To some extent. Once- through smHTGR spent fuel can be stored safely in qualified } \\
\text { transport and storage casks. The lower decay heat power density of the large volume } \\
\text { HTGR fuel along with the robust fuel form allows the fuel to be transferred more }\end{array}$ \\
\hline
\end{tabular}




\begin{tabular}{|c|c|}
\hline Criteria & Small Modular High Temperature Reactor (smHTR) \\
\hline & quickly from water-cooled storage to air-cooled containers. \\
\hline $\begin{array}{l}\text { 5) Is a reprocessing capability } \\
\text { required? If yes, what type of } \\
\text { technology is needed, has it been } \\
\text { proven/demonstrated, and what } \\
\text { are the waste forms? }\end{array}$ & $\begin{array}{l}\text { Reprocessing is not required. HTGR fuel can be reprocessed but this requires } \\
\text { additional steps to remove the graphite element, break the coatings, and leach out the } \\
\text { kernel materials for subsequent reprocessing. }\end{array}$ \\
\hline $\begin{array}{l}\text { 6) Discuss any unique } \\
\text { features/aspects of } \\
\text { processing/storage/transportation } \\
\text { of used fuel, high level waste } \\
\text { (HLW), or LLW. }\end{array}$ & $\begin{array}{l}\text { The particle coatings and matrix also provide an additional barrier to FP release. The } \\
\text { volume of spent fuel, per MWe generated, however, is much higher owing to the } \\
\text { graphite matrix that forms the bulk of the fuel element. The decay heat density is, } \\
\text { however, comparably lower. Depending upon the limits and costs of spent fuel } \\
\text { management, it may be desirable for the operator to have the coated particles } \\
\text { separated from the graphite element to reduce HLW volume. The graphite may be } \\
\text { decontaminated and re-used (research is underway particularly in Europe). }\end{array}$ \\
\hline \multirow{9}{*}{$\begin{array}{l}\text { 7) Describe how the ARC is } \\
\text { compatible with IAEA } \\
\text { safeguards guidance of reactor } \\
\text { and associated fuel cycle } \\
\text { facilities. }\end{array}$} & $\begin{array}{l}\text { Current guidance is applicable. Safeguards approaches for LWR fuel can be applied to } \\
\text { the prismatic HTGR [11]. }\end{array}$ \\
\hline & $\begin{array}{l}\text { The HTR Modul, being fueled online with small pebbles, has unique features with } \\
\text { regard to safeguards [12]. }\end{array}$ \\
\hline & $\begin{array}{l}\text { - The pebble fuel HTGR is an on-load refueled reactor, and in this respect is more } \\
\text { akin to the Canadian Deuterium/Uranium (CANDU) reactor }\end{array}$ \\
\hline & $\begin{array}{l}\text { - The pebble fuel assemblies are more small and numerous, and consequently are } \\
\text { more challenging to count due to the greater number in the core (several hundred } \\
\text { thousand) }\end{array}$ \\
\hline & $\begin{array}{l}\text { - Startup of the pebble fuel HTGR core requires an initial loading of graphite } \\
\text { moderator pebbles, which are drawn down as the reactor reaches nuclear } \\
\text { equilibrium }\end{array}$ \\
\hline & $\begin{array}{l}\text { - Verifying pebble fuel and distinguishing it from pebble moderator is a new } \\
\text { safeguards issue }\end{array}$ \\
\hline & $\begin{array}{l}\text { - After the pebble fuel HTGR reaches nuclear equilibrium, spent fuel is } \\
\text { continuously removed and fresh fuel transferred to the core to take its place }\end{array}$ \\
\hline & $\begin{array}{l}\text { The flow of fuel to and from the pebble fuel HTGR core follows a more elaborate } \\
\text { flow scheme and requires greater attention in monitoring fuel transfers, because } \\
\text { the pebble fuel is smaller and the movements concealed below the reactor } \\
\text { building floor }\end{array}$ \\
\hline & $\begin{array}{l}\text { - Because of the greater number of inventory and flow key measurement points } \\
\text { (KMP), the pebble fuel HTGR requires containment and surveillance measures at } \\
\text { more locations (relative to an LWR). }\end{array}$ \\
\hline \multicolumn{2}{|c|}{$\begin{array}{l}\text { Category VII. Assessment of market attractiveness (e.g., efficiency, initial capital costs, application beyond electricity } \\
\text { generation, etc.) }\end{array}$} \\
\hline $\begin{array}{l}\text { 1) Energy products of the ARC } \\
\text { (e.g. electricity production, } \\
\text { desalination, process heat, } \\
\text { hydrogen production, etc.) and } \\
\text { its power (thermal, electric) } \\
\text { output and/or product output. }\end{array}$ & $\begin{array}{l}\text { The high outlet temperature of the smHTGR is well-suited for providing a wide range } \\
\text { of process heat-driven applications. The technical and economic feasibility of } \\
\text { integrating the HTGR into various industrial processes was assessed and documented } \\
\text { in[13]. These applications included: seawater desalination, ex situ and in situ oil shale } \\
\text { retort, oil sands recovery, coal-to-liquids and gas to liquids conversion. The economic } \\
\text { viability of the nuclear-driven process varies with the application and none are } \\
\text { currently competitive with fossil fuels for providing heat, in some cases such as } \\
\text { coal-to-liquids conversion the HTGR-driven process can compete with natural gas at } \\
\text { historic levels. }\end{array}$ \\
\hline $\begin{array}{l}\text { 2) Expected thermal to electric } \\
\text { conversion efficiency, and } \\
\text { overall multi-use plant } \\
\text { efficiency. }\end{array}$ & The thermal-to-electric efficiency is $\sim 40 \%$ when driving a conventional steam cycle. \\
\hline $\begin{array}{l}\text { 3) Estimated capital and operating } \\
\text { costs (compared with current } \\
\text { LWRs). }\end{array}$ & $\begin{array}{l}\text { A cost model was developed with input from reactor vendors as part of the NGNP } \\
\text { project. Capital, operating, and decommissioning costs were estimated for an } 850 \mathrm{C} \\
\text { HTGR with either a } 350 \mathrm{MWt} \text { or } 600 \mathrm{MWt} \text { output and single or '4-pack' deployment. } \\
\text { These were documented in[14] and shown in Table } 4 \text {. }\end{array}$ \\
\hline
\end{tabular}




\begin{tabular}{|c|c|}
\hline Criteria & Small Modular High Temperature Reactor (smHTR) \\
\hline $\begin{array}{l}\text { 4) Estimated siting requirements } \\
\text { (e.g., less water usage or } \\
\text { accident consequences may } \\
\text { favorably impact siting } \\
\text { requirements). }\end{array}$ & $\begin{array}{l}\text { The HTGR is suitable for deployment at a wide variety of sites. The source term will } \\
\text { be lower than that of an LWR as will cooling requirements on a per MWt basis. The } \\
\text { reactor vessel will be seismically isolated. } \\
\text { Dry cooling has been evaluated as an option for HTGR deployment in arid regions. } \\
\text { This reduces the plant output. } \\
\text { As originally designed, the MHTGR can withstand a maximum free-field acceleration } \\
\text { of } 0.15 \mathrm{~g} \text { during operation and } 0.30 \mathrm{~g} \text { for a Safe Shutdown Earthquake9. As originally } \\
\text { designed, the HTR Modul can withstand a maximum free-field acceleration of } 0.15 \mathrm{~g} \\
\text { during operation and } 0.30 \mathrm{~g} \text { for a Safe Shutdown Earthquake. } \\
\text { A scoping evaluation of siting an HTGR cogeneration plant at an existing US nuclear } \\
\text { plant site was performed an documented in [15]. Similar evaluations were performed } \\
\text { for siting an HTGR at other sites such as an existing petrochemical plant. }\end{array}$ \\
\hline $\begin{array}{l}\text { 5) Environmental impacts under } \\
\text { normal/abnormal conditions, } \\
\text { including severe accident } \\
\text { conditions, and from spent fuel } \\
\text { arrangements (as compared with } \\
\text { current LWRs). }\end{array}$ & $\begin{array}{l}\text { The smHTGR will meet siting regulations specified in NRC's } 10 \text { CFR } 100 \text { and section } \\
8 . c .7 \text { of DOE order } 5480.30 \text {. It is expected that the small reactor source term will be } \\
\text { much smaller, resulting in reduced environmental impact (but comparable to an LWR } \\
\text { on a per MWt basis). }\end{array}$ \\
\hline $\begin{array}{l}\text { 6) Competitiveness on international } \\
\text { markets/export potential. } \\
\text { Specifically, what ARC features } \\
\text { could make it desirable to a } \\
\text { foreign customer? }\end{array}$ & $\begin{array}{l}\text { The smaller output would make the smHTGR more attractive for nations with lower } \\
\text { capacity grids and expected growth. Co-generation of electricity and process heat may } \\
\text { be desirable for remote industrial operations such as oil sand recovery in northern } \\
\text { Canada. Water desalination options using smHTGR designs are particularly attractive } \\
\text { to arid Gulf states. The smaller emergency planning zone enables collocation of } \\
\text { industrial operations. }\end{array}$ \\
\hline $\begin{array}{l}\text { 7) Derived technologies arising } \\
\text { from ARC development. }\end{array}$ & $\begin{array}{l}\text { Hydrogen production was a primary goal of the early NGNP project and various } \\
\text { hydrogen production technologies are still being developed with HTR projects around } \\
\text { the world. Hybrid energy systems (electricity + process heat) developed in } \\
\text { conjunction with HTGRs continue to attract research funding. Accident-tolerant } \\
\text { TRISO fuel is being explored for other advanced reactor concepts. }\end{array}$ \\
\hline 8) Unique features. & $\begin{array}{l}\text { High outlet temperature, low power density core with high thermal inertia, melt-proof } \\
\text { fuel, very low fission product release rate enabling a reduced emergency planning } \\
\text { zone suitable for collocation of industrial operations. }\end{array}$ \\
\hline $\begin{array}{l}\text { 9) Expected time frame of } \\
\text { introducing the ARC to the } \\
\text { market. }\end{array}$ & $\begin{array}{l}\text { The schedule for deployment of the first NGNP was most recently updated in } 2011 \\
\text { and specified a span of } 17 \text { years between the commencement of R\&D and licensing } \\
\text { activities and full operation of the first HTGR, with R\&D activities continuing } \\
\text { through to the end particularly in fuel qualification. Although the expected level of } \\
\text { funding for the project did not materialize, considerable progress in R\&D and } \\
\text { licensing has occurred. Under the schedule projected from } 2013 \text {, fuel qualification } \\
\text { will be largely completed by } 2021 \text {. About } 5 \text { years are needed for the fuel vendor to set } \\
\text { up the production line and fabricate the first core. Assuming that R\&D, licensing, } \\
\text { construction and fuel production activities are conducted in parallel, the first plant } \\
\text { could operate in } 8-10 \text { years. }\end{array}$ \\
\hline \multicolumn{2}{|c|}{ Category VIII. Economics (including construction, manufacturing, and operating costs, uncertainties) } \\
\hline $\begin{array}{l}\text { 1) The extent and ability to use } \\
\text { pre-fabricated modular } \\
\text { construction for plant structures } \\
\text { and systems. The materials and } \\
\text { features of proposed modules } \\
\text { that would improve the ARC } \\
\text { economics. }\end{array}$ & $\begin{array}{l}\text { Modular construction techniques will be used to the extent possible. The vessel for a } \\
350 \mathrm{MWt} \text { HTGR is still large (comparable to an LWR) as are some of the other } \\
\text { components so complete factory fabrication is unlikely. Helium circuit components } \\
\text { are smaller than comparable LWR pumps and turbines. }\end{array}$ \\
\hline $\begin{array}{l}\text { 2) ARC improved economics by } \\
\text { simplified design compared with } \\
\text { LWRs (e.g. length of piping, } \\
\text { electrical cables, valves, number } \\
\text { of loops, pool design, etc.). }\end{array}$ & $\begin{array}{l}\text { The primary advantage arises from the elimination of active safety systems. Further } \\
\text { savings can be realized in that the balance of plant components are smaller than those } \\
\text { used in a large LWR. }\end{array}$ \\
\hline 3) Cost of nuclear fuel. & The table under Estimated Capital and Operating costs (from [14]) included values for \\
\hline
\end{tabular}




\begin{tabular}{|c|c|}
\hline Criteria & Small Modular High Temperature Reactor (smHTR) \\
\hline & the fuel. \\
\hline $\begin{array}{l}\text { 4) Cost of major components. Need } \\
\text { for special materials and/or } \\
\text { construction methods (how many } \\
\text { large vessels and pipes have to } \\
\text { be fabricated, and how large } \\
\text { would they have to be?). }\end{array}$ & $\begin{array}{l}\text { Reference }{ }^{14} \text { includes estimates of itemized costs for major components. Except for } \\
\text { the graphite which is readily available, LWR materials and construction methods can } \\
\text { be employed. }\end{array}$ \\
\hline $\begin{array}{l}\text { 5) Estimated construction schedule } \\
\text { (as compared with LWRs). }\end{array}$ & For the original MHTGR design, a 33 month construction schedule was assumed. \\
\hline $\begin{array}{l}\text { 6) Special skill sets and/or } \\
\text { procedures required for }\end{array}$ & $\begin{array}{l}\text { The first smHTGR will require special skilled labor during construction since this is } \\
\text { first-of-a-kind facility. }\end{array}$ \\
\hline $\begin{array}{l}\text { construction and their } \\
\text { availability. }\end{array}$ & $\begin{array}{l}\text { Plant systems and components related to the helium coolant, instrumentation and } \\
\text { control (I\&C), special core design, shielding, special fuel transfer and handling, etc., } \\
\text { are substantially different than LWRs. The labor force will have to be trained. }\end{array}$ \\
\hline & $\begin{array}{l}\text { The technology and skills to manufacture the fuel is being developed in cooperation } \\
\text { with a commercial fuel vendor. }\end{array}$ \\
\hline 7) Estimated overnight capital cost. & See the table listed under Estimated Capital and Operating costs (from [14]). \\
\hline $\begin{array}{l}\text { 8) Estimated yearly operational cost } \\
\text { (accounting for } \\
\text { decommissioning and waste } \\
\text { management). }\end{array}$ & See the table listed under Estimated Capital and Operating costs (from [14]). \\
\hline 9) Estimated cost of electricity. & $\begin{array}{l}\text { The HTGR cost model developed under the NGNP project estimates the cost to } \\
\text { produce electricity with an HTGR to be between } 70 \text { and } 80 \$ / \mathrm{MWhe}[16] \text {. The } \\
\text { estimated cost to produce steam with an HTGR is } 10-15 \$ / 1000 \mathrm{lbs} \text {. }\end{array}$ \\
\hline \multicolumn{2}{|c|}{ Category IX. Potential regulatory licensing environment (advantages and uncertainties/risks) } \\
\hline \multirow{3}{*}{$\begin{array}{l}\text { 1) A description of the licensing } \\
\text { approach envisioned for the } \\
\text { proposed ARC. This would } \\
\text { include the general applicability } \\
\text { of current regulatory } \\
\text { requirements (10 Code of } \\
\text { Federal Regulations (CFR) } 50 \text {, } \\
\text { 52) and guidance documents } \\
\text { (e.g., NUREG-0800 and } \\
\text { Regulatory Guides) to ARC } \\
\text { design, construction, and } \\
\text { operating licensing. }\end{array}$} & $\begin{array}{l}\text { The overall licensing approach for the NGNP was developed by a joint DOE and NRC } \\
\text { working group, to establish a viable licensing path that would support the deployment } \\
\text { schedule directed by EPAct } 2005 \text {. That agreed upon licensing strategy and approach } \\
\text { was summarized in a report to Congress [17] in } 2008 \text {. }\end{array}$ \\
\hline & $\begin{array}{l}\text { The NGNP project team then developed a more specific and detailed plan for } \\
\text { implementing the licensing strategy. This NGNP Licensing Plan [18] from } 2009 \\
\text { identified and prioritized the plan for addressing the key HTGR licensing policy and } \\
\text { technical issues, and established an approach for developing the required license } \\
\text { application content. It has provided the basis for the NGNP licensing activities and } \\
\text { NRC interactions implemented during the past five years. }\end{array}$ \\
\hline & $\begin{array}{l}\text { As a part of its implementation of the Plan, the NGNP team performed a } \\
\text { comprehensive regulatory gap analysis, which included a review of over } 2600 \\
\text { regulations and associated NRC regulatory guidance to identify areas requiring } \\
\text { revision and/or adaptation to support NGNP licensing. The results of that analysis [19] } \\
\text { concluded that a relatively small number of regulations would require revision/update } \\
\text { to support modular HTGR licensing. }\end{array}$ \\
\hline \multirow{5}{*}{$\begin{array}{l}\text { 2) ARC design/operational features } \\
\text { that positively impact licensing } \\
\text { requirements (reduced } \\
\text { radioactive inventory, enhanced } \\
\text { passive safety, low-pressure } \\
\text { operation, etc.). }\end{array}$} & $\begin{array}{l}\text { The design is consistent with the NRC's Advanced Reactor Policy Statement (the } \\
\text { incorporation of inherent or passive means for reactor shutdown and heat removal, } \\
\text { longer time constants, simplified safety systems which reduce required operator } \\
\text { actions, etc.) }\end{array}$ \\
\hline & $\begin{array}{l}\text { Specifically, the HTGR designs for NGNP utilize the following inherent material } \\
\text { properties: }\end{array}$ \\
\hline & $\begin{array}{l}\text { - Helium coolant - neutronically transparent, chemically inert, low heat } \\
\text { capacity, single phase }\end{array}$ \\
\hline & $\begin{array}{l}\text { - Ceramic coated fuel - high temp capability, high radionuclide retention } \\
\text { - Graphite moderator - high temp stability, large heat capacity, long response } \\
\text { times }\end{array}$ \\
\hline & $\begin{array}{l}\text { In addition, the modular HTGR was developed as a simple modular reactor design } \\
\text { with passive safety, including the following characteristics: }\end{array}$ \\
\hline
\end{tabular}




\begin{tabular}{|c|c|}
\hline Criteria & Small Modular High Temperature Reactor (smHTR) \\
\hline & $\begin{array}{l}\text { - Radionuclides are retained at their source within the fuel } \\
\text { - The reactor is sized and configured for passive core heat removal from } \\
\text { depressurized helium primary coolant } \\
\text { - There is a large negative temperature coefficient for intrinsic reactor } \\
\text { shutdown } \\
\text { - There is no reliance on AC-power } \\
\text { - There is no reliance on operator action and the design is insensitive to } \\
\text { incorrect operator actions } \\
\text { Additional information regarding the safety basis for the modular HTGR can be found } \\
\text { in [10]. }\end{array}$ \\
\hline $\begin{array}{l}\text { 3) ARC design/operational features } \\
\text { that have not been subject to the } \\
\text { licensing process for the current } \\
\text { fleet of LWRs, or if the proposed } \\
\text { ARC design/operational features } \\
\text { do not include features typically } \\
\text { found in LWRs. }\end{array}$ & $\begin{array}{l}\text { There are a number of design/operational features of the modular HTGR that have not } \\
\text { been previously licensed in association with the current fleet of LWRs. These features } \\
\text { and the path to successful licensing were the primary subject of the joint NRC-DOE } \\
\text { Licensing Strategy (Ref. A), which established an approach for adapting the existing } \\
\text { regulatory requirements to address the modular HTGR. } \\
\text { In particular, the proposed approach, which has been implemented by NGNP, } \\
\text { addresses the following key items that are different from LWR fleet licensing: } \\
\text { - Establishment of a design and licensing basis event identification process } \\
\text { that is based on a risk informed performance based approach } \\
\text { Definition and implementation of a mechanistic source term concept for } \\
\text { establishing the types and levels of radionuclide releases that must be } \\
\text { considered from licensing basis events } \\
\text { One feature found in all LWRs that is not included in the modular HTGR design and } \\
\text { licensing concept is a pressure retaining primary containment structure. Protection of } \\
\text { public health and safety is instead provided by a functional containment that relies on } \\
\text { the radionuclide retention capabilities of the TRISO fuel (kernels, coatings, and } \\
\text { graphite element) in conjunction with additional radionuclide release barriers that } \\
\text { include the helium pressure boundary and the reactor building. } \\
\text { This approach and the specific NGNP proposals in the above areas have been } \\
\text { extensively reviewed by the NRC staff, and they have developed a set of draft } \\
\text { assessment reports that conclude that the NGNP proposals are generally reasonable. } \\
\text { The NRC's formal issuance of these reports is expected in the near term. }\end{array}$ \\
\hline $\begin{array}{l}\text { 4) Applicability of current codes } \\
\text { and standards and possible } \\
\text { development required. }\end{array}$ & $\begin{array}{l}\text { For elevated temperature metallic pressure boundary components and core support } \\
\text { structures, the applicable structural design code is the ASME Boiler and Pressure } \\
\text { Vessel Code, Section III, Division 5, Subsections HB, HC and HG and applicable } \\
\text { code cases. Currently, rules in Division } 1 \text {, Subsections NB, NG and NH are referenced } \\
\text { in these Division } 5 \text { subsections. There is plan to directly incorporate Subsection NH } \\
\text { into Division } 5 \text { and simultaneously delete Subsection NH. } \\
\text { The applicable design rules for the short term elevated temperature excursions during } \\
\text { loss of flow and loss of coolant accident scenarios of the actively cooled RPV made of } \\
\text { low alloy steels in the reference design are provided in Division } 5 \text { Subsection HB, } \\
\text { Subpart B appendix. } \\
\text { As described in previous criteria sections, Alloy } 800 \mathrm{H} \text { and } 2{ }^{1} / 4 \mathrm{Cr}-1 \mathrm{Mo} \text { steel (solution } \\
\text { annealed) are currently qualified in Subsection NH, and hence by reference, in } \\
\text { Division } 5 \text { for up to } 300,000 \text { hours and } 760^{\circ} \mathrm{C} \text { and } 593^{\circ} \mathrm{C} \text {, respectively. Extension to } \\
\text { beyond } 300,000 \text { hours for these two materials is required to support design lifetimes } \\
\text { that are greater than } 40 \text { years. } \\
\text { Recently, concerns have been raised by ASME code committees on the applicability } \\
\text { of existing simplified design methods near the upper temperature limits of Subsection } \\
\text { NH materials (including Alloy } 800 \mathrm{H} \text { and solution-annealed } 21 / 4 \text { Cr- } 1 \text { Mo steel). R\&D } \\
\text { on development and qualification of appropriate simplified design methodologies for } \\
\text { these two materials is required. There is also a lack of inelastic analysis methods for } \\
\text { these two materials; hence, R\&D on unified constitutive model development and finite } \\
\text { element implementation is required. } \\
\text { Alloy } 617 \text { is being qualified for up to } 950^{\circ} \mathrm{C} \text { and } 100,000 \text { hours for Subsection } \mathrm{NH}\end{array}$ \\
\hline
\end{tabular}




\begin{tabular}{|c|c|}
\hline Criteria & Small Modular High Temperature Reactor (smHTR) \\
\hline & $\begin{array}{l}\text { applications to support a } 950^{\circ} \mathrm{C} \text { outlet ARC. It is anticipated that the code committee } \\
\text { approval process will be completed by FY17. } \\
\mathrm{R} \& \mathrm{D} \text { on design rules and methods for post-construction examination and in-service } \\
\text { inspections for compact heat exchanger design is needed. } \\
\mathrm{R} \& \mathrm{D} \text { on design rules and analysis method for dissimilar metal weld joints to support } \\
\text { steam generator design is required. }\end{array}$ \\
\hline $\begin{array}{l}\text { 5) Applicability of current analysis } \\
\text { tools and data (new R\&D } \\
\text { needed). }\end{array}$ & $\begin{array}{l}\text { Long term creep, aging, environmental and crack growth data are needed for Alloy } \\
617 \text {, Alloy } 800 \mathrm{H} \text { and solution-annealed } 21 / 4 \mathrm{Cr}-1 \mathrm{Mo} \text { steel, and their weldments } \\
\text { (including dissimilar metal weld joints), to support NRC licensing. The actively } \\
\text { cooled RPV is designed to operate at temperatures below the ASME code temperature } \\
\text { boundary of } 371^{\circ} \mathrm{C} \text { but higher than the operating temperatures of light water reactors, } \\
\text { hence these data are also needed to support NRC licensing. } \\
\text { Long term emissivity data for reactor pressure vessel materials in impure helium and } \\
\text { neutron irradiation environment are needed to support the adequacy of passive decay } \\
\text { heat removal during accident scenarios. } \\
\text { Tools developed for LWR safety analysis have been modified for HTGR use. } \\
\text { Performance against available benchmarks and experiments indicates that these tools } \\
\text { can be successfully deployed. It is likely, however, that the regulator will require } \\
\text { additional validation and verification of the tools before they will accept the results as } \\
\text { part of a license application. Some validation experiments began under the NGNP } \\
\text { program and continue at a modest level. } \\
\text { Certain phenomena and scenarios, such as natural circulation heating of the upper } \\
\text { vessel head during a pressurized loss of forced cooling, cannot be modeled adequately } \\
\text { with traditional system codes. These require computational fluid dynamics codes } \\
\text { which have not been accepted by the NRC for HTGR safety analysis. Without such } \\
\text { analyses and associated standards, the extra conservatism will need to be built into the } \\
\text { design. } \\
\text { NRC has sponsored the development of a tool set that can assess the coupled } \\
\text { neutronics and thermal fluids behavior of both prismatic and pebble bed HTGR } \\
\text { systems at the University of Michigan. These tools were applied in both international } \\
\text { code-to-code benchmarks that were conducted under the auspices of the OECD for } \\
\text { pebble bed ( } 2005-2010 \text { ) and prismatic designs ( } 2011-2015) \text {. }\end{array}$ \\
\hline $\begin{array}{l}\text { 6) Knowledge base and skills of } \\
\text { NRC staff to address ARC } \\
\text { design and licensing. }\end{array}$ & $\begin{array}{l}\text { Experimental validation of safety analysis codes for loss of forced cooling events and } \\
\text { ex-core heat removal. A consortium of universities and Argonne National Laboratory } \\
\text { are completing experiments that re-create the performance of the Reactor Cavity } \\
\text { Cooling System. The university work on air-and water-cooled RCCS code validation } \\
\text { will be completed by } 2016 \text {. ANL is completing experiments on air-cooled RCCS after } \\
\text { which the facility will be reconfigured to validate water-cooled simulations. } \\
\text { Tests using the High Temperature Test Facility at Oregon State University will begin } \\
\text { later in } 2014 \text {. These tests are funded mostly by the NRC and will re-create the } \\
\text { conditions following various types of breaks in the primary system Loosely-related } \\
\text { experiments in bypass flow, air ingress, core heat transfer, and plenum-to-plenum heat } \\
\text { transfer are underway or are planned. Complementary analyses with CFD and the } \\
\text { RELAP5-3D system code are being performed at INL and ANL. } \\
\text { These two efforts will provide much of the data needed to validate smHTR } \\
\text { simulations as long as they are completed. The NRC may require further experiments } \\
\text { to validate system and CFD codes for specific phenomena or sceanrios. The codes } \\
\text { used in a license application will require this data for validation and further work for } \\
\text { verification. }\end{array}$ \\
\hline $\begin{array}{l}\text { 7) Estimated validation and } \\
\text { verification effort (tests and } \\
\text { computer codes). }\end{array}$ & HTTF, NSTF methods budget \\
\hline $\begin{array}{l}\text { 8) Identification of any additional } \\
\text { regulatory activities or products, } \\
\text { such as previous NRC reviews or } \\
\text { research efforts, that could } \\
\text { enhance the licensability of the } \\
\text { ARC. }\end{array}$ & $\begin{array}{l}\text { The NRC has previously engaged in a number of efforts that enhance the capability to } \\
\text { license smHTRs. Those NRC efforts have included: } \\
\text { Licensing and operational oversight of the Fort St. Vrain facility (late } 70 \mathrm{~s} \\
\text { through early } 80 \mathrm{~s} \text { ) } \\
\text { - Interactions with DOE regarding the proposed New Production Reactor }\end{array}$ \\
\hline
\end{tabular}




\begin{tabular}{|c|c|}
\hline Criteria & Small Modular High Temperature Reactor (smHTR) \\
\hline & $\begin{array}{l}\text { - Review of the GA Modular High Temperature Gas Cooled Reactor } \\
\text { (MHTGR) license application material, which resulted in issuance of a draft } \\
\text { Safety Evaluation Report (documented in NUREG-1338, issued in } 1989 \text { and } \\
\text { updated in 1995) } \\
\text { - Engagement in Exelon pre-licensing efforts in } 1999-2001 \text { associated with } \\
\text { licensing a pebble bed modular reactor } \\
\text { - Engagement with Pebble Bed Modular Reactor (PBMR) Ltd. pre-licensing } \\
\text { activities in 2005-2006 } \\
\text { - Joint development, with DOE, of the NGNP Licensing Strategy - A Report } \\
\text { To Congress (August 2008) } \\
\text { Development and implementation of the NRC's Advanced Reactor } \\
\text { Research Plan (March 2011) - focused primarily on HTGRs and reviewed } \\
\text { by NRC's Advisory Committee on Reactor Safeguards } \\
\text { Significant interactions with the NGNP project (2008 - 2013) to address and } \\
\text { resolve the key licensing and policy issues associated with modular HTGRs. } \\
\text { It is noted that NRC plans to issue a series of assessment reports in the near term } \\
\text { documenting the results of its reviews of the NGNP project pre-licensing proposals. } \\
\text { Those reports will provide key inputs and insights regarding advanced (non-light } \\
\text { water) reactor licensing that will likely be very useful in the development of both the } \\
\text { smHTR and other advanced reactor design types. }\end{array}$ \\
\hline $\begin{array}{l}\text { 9) The effect of unique fuel } \\
\text { configurations on the licensing } \\
\text { requirements for storage of spent } \\
\text { nuclear fuel. In addition to the } \\
\text { relevant regulatory requirements } \\
\text { in } 10 \text { CFR Parts } 20,50 \text {, and } 52 \text {, } \\
\text { the applicant should address any } \\
\text { unique issues of how the } \\
\text { requirements of } 10 \text { CFR Part } 72 \\
\text { would impact long-term storage } \\
\text { of spent nuclear fuel. }\end{array}$ & $\begin{array}{l}\text { Currently, There are no unique fuel configurations for smHTRs that would create } \\
\text { issues associated with the requirements of } 10 \text { CFR Part } 72 \text {. } \\
\text { It is noted that coated particle fuel waste characteristics are different than those for } \\
\text { LWR spent fuel. NRC regulations } 10 \text { CFR } 51.51 \text {, Table S-3, "Uranium Fuel Cycle } \\
\text { Environmental Data" and } 10 \text { CFR } 51.52 \text {, Table S-4, "Environmental Effects of } \\
\text { Transportation of Fuel and Waste" address LWRs but not HTGRs. }\end{array}$ \\
\hline \multicolumn{2}{|l|}{ Category X - Nonproliferation } \\
\hline $\begin{array}{l}\text { 1) Characteristics of the fresh and } \\
\text { spent/used fuel. }\end{array}$ & $\begin{array}{l}\text { An UCO-fueled HTR Modul fuel element is a } 6 \mathrm{~cm} \text { (o.d.) mostly graphite pebbles } \\
\left(184.5 \mathrm{~cm}^{3} \text { effective volume and } 205 \mathrm{~g} \text { each) containing } 19,000 \text { coated particles of }\right. \\
\text { LEU. Each fresh pebble contains } 7.1 \mathrm{~g} \text { of } 14 \% \text { enriched uranium }(\sim 1 \mathrm{~g} \mathrm{U}-235) \text {. } \\
\text { To get a significant quantity of U-235 }(75 \mathrm{~kg}) \text { one requires about } 75,000 \text { pebbles. A } \\
\text { single reactor contains }<400,000 \text { pebbles during operation or about } 5 \mathrm{x} \text { an SQ of U- } \\
235 . \\
\text { With } 15 \% \text { enriched fuel, the HTR Modul would consume approximately } 180 \text { fresh } \\
\text { pebbles per day and discharges the same amount of spent pebbles to its Used Fuel } \\
\text { Container. Each pebble discharged from the core }(\sim 166 \mathrm{MWD} / \mathrm{kghm}) \text { contains } \\
\text { roughly the following: } \\
\mathrm{U}-235: \quad 48 \mathrm{mg} \\
\text { Pu-238: } 7 \mathrm{mg} \\
\text { Pu-239: } 42 \mathrm{mg} \\
\text { Pu-240: } 28 \mathrm{mg} \\
\text { Pu-241: } 19 \mathrm{mg} \\
\text { Pu-242: } 28 \mathrm{mg} \\
\text { Pu-total: } 0.172 \mathrm{~g} \\
\text { U-238 and Mixed Fission Products: } \sim 6.88 \mathrm{~g} \\
\text { All of the pebbles discharged from the core will have a high radiation dose and can be } \\
\text { expected to remain on site in the Used and Spent Fuel Containers. }\end{array}$ \\
\hline $\begin{array}{l}\text { 2) Other design characteristics that } \\
\text { impact the materials control and } \\
\text { accounting system (and whether } \\
\text { significant development of a }\end{array}$ & $\begin{array}{l}\text { The HTR Modul and the MHTGR are in an early stage of engineering development; } \\
\text { as the designs progress there will be more detail on how appropriate materials, } \\
\text { control, and accounting methodology will be established to ensure that fuel is } \\
\text { protected from theft or diversion. }\end{array}$ \\
\hline
\end{tabular}




\begin{tabular}{|c|c|}
\hline Criteria & Small Modular High Temperature Reactor (smHTR) \\
\hline $\begin{array}{l}\text { materials control and accounting } \\
\text { methodology will be needed). }\end{array}$ & $\begin{array}{l}\text { Conceptually, verification of the nuclear content of fresh pebble fuel casks can be } \\
\text { accomplished using NDA verification systems similar to those used for LEU fuel and } \\
\text { MOX materials. The gross and net weight of pebble fuel casks may be accomplished } \\
\text { using load cells or operator weighing systems. } \\
\text { A primary means of spent fuel verification could be established using a pebble fuel } \\
\text { flow monitor, this would be used to distinguish spent fuel from damaged, irradiated, } \\
\text { and fresh pebble fuel and graphite pebble moderator. Spent fuel could then be } \\
\text { verified to detect the substation of damaged, irradiated, or spent fuel with a non-fuel } \\
\text { object (such as graphite pebble moderator). } \\
\text { As the design of the HTGR reactors progresses, the materials, control and accounting } \\
\text { methodology will be developed along with details of the operational and safety } \\
\text { aspects of the plant[11,12]. This will ensure that the SNM will be more than } \\
\text { adequately protected. }\end{array}$ \\
\hline $\begin{array}{l}\text { 3) Operational concept for the } \\
\text { design as may impact } \\
\text { proliferation risk. }\end{array}$ & $\begin{array}{l}\text { A government which plans to divert nuclear material may find the continual loading } \\
\text { and unloading of pebbles in the HTR Modul to be an attractive source of material. If } \\
\text { the plant were operated by the state, the unloaded pebbles could potentially be } \\
\text { diverted and replaced with a different material. } \\
\text { One way of decreasing the likelihood of diversion success is to ensure that the } \\
\text { regulatory agency that monitors nuclear materials (IAEA) has a way of verifying that } \\
\text { the particular fuel pebble that is supposed to be in the used fuel storage area is actually } \\
\text { there. This can be achieved by finding a way to uniquely mark each pebble so that it } \\
\text { can be identified while in storage, i.e., by making each fuel assembly "inspectable." } \\
\text { Frequent refueling can also allow a government frequent access to the interior of the } \\
\text { pool near the reactor core. This could potentially provide easy access for a } \\
\text { government to irradiate material for future use as a weapon. This is most effectively } \\
\text { considered via the use of a safety, security, and safeguards by design (3S by Design) } \\
\text { program. } 3 \mathrm{~S} \text { by Design advocates developing a team of professionals with expertise in } \\
\text { each of the three areas of concern to work together from the conceptual design phase } \\
\text { to ensure that a globally optimized } 3 \mathrm{~S} \text { program is developed via the use of Systems } \\
\text { Engineering principles. } \\
\text { The use of SBD to aid in developing these fuel handling procedures and to ensure that } \\
\text { these operations do not cause undue stress on other operational aspects of the plant } \\
\text { would seem to be a necessary step. }\end{array}$ \\
\hline $\begin{array}{l}\text { 4) Relevant integral } \\
\text { nonproliferation and security } \\
\text { perspectives (e.g. material } \\
\text { attractiveness of fuel considered } \\
\text { in the context of anticipated } \\
\text { security features/operational } \\
\text { concept). }\end{array}$ & $\begin{array}{l}\text { One issue of concern here is the potential to remove HTR Modul pebbles by the state } \\
\text { in order to obtain a significant quantity of nuclear material for development of a } \\
\text { weapon. The material accountability aspects of online refueling should be considered } \\
\text { in detail and in concert with safety, security, and operations design personnel. }\end{array}$ \\
\hline
\end{tabular}




\section{References}

1. "NGNP Program 2013 Status and Path Forward", INL/EXT-14-31035, March 2014.

2. Safety Analysis Report for the High Temperature Reactor Module Power Plant, April 1987.

3. Lohnert, G. H., "Technical Design Features and Essential Safety-Related Properties of the HTRModule", Nuclear Engineering and Design 121, pp. 259-275, 1990.

4. Strydom, G. and Gougar, H., "Preliminary Reactor Physics Assessment of the HTR Module with 14\% enriched USO fuel", Nuclear Engineering and Design 256, pp. 304-321, 2013.

5. Personal Correspondence between Chris Ellis (General Atomics) and Javier Ortensi (INL), 18 March, 2014.

6. INL “NGNP System Requirements Manual," INL/EXT-07-12999, Revision 3, September 2009.

7. INL, Research and Development Technology Development Roadmaps for the Next Generation Nuclear Plant Project," INL/EXT-11-22512, July 2011

8. INL, Reactor User Interface Technology Development Roadmaps for a High Temperature Gas-cooled Reactor Outlet Temperature of $750^{\circ} \mathrm{C}$, INL/EXT-10-20460, December 2010.

9. MHTGR PSID - DOE-HTGR-86-024.

10. Modular High Temperature Gas-Cooled Reactor Safety Basis and Approach, INL/EXT-13-30872, January 2014.

11. Durst, P. C., Safeguards-by-Design: Guidance for High Temperature Reactors (HTGRs) with Prismatic Fuel, INL/EXT-12-26130, August 2012.

12. Durst, P. C. Safeguards-by-Design: Guidance for High Temperature Reactors (HTGRs) with Pebble Fuel, INL/EXT-12-26561, August 2012.

13. Nelson, L., "Integration of High Temperature Gas-Cooled Reactors into Industrial Process Applications, INL/EXT-09-16942, Rev. 3, September 2011.

14. Gandrik, A. and Wallace, B., “ Assessment of High Temperature Gas-Cooled Reactor (HTGR) Capital and Operating Costs, TEV-1196, Idaho National Laboratory report, January 2012.

15. Next Generation Nuclear Plant Evaluation of Siting an HTGR C0-generation Plant on an Operating Commercial Nuclear Plant Site, INL/EXT-11-23282, Rev. 1, October 2011.

16. High Temperature Gas-Cooled Reactor Projected Markets and Preliminary Economics, INL/EXT-10-19037, August 2011.

17. Next Generation Nuclear Plant Licensing Strategy - A Report to Congress, August 2008.

18. NGNP Licensing Plan, PLN-3202, Rev. 0, 6/26/09.

19. NGNP Project Regulatory Gap Analysis for Modular HTGRs, INL/EXT-11-23216, September 2011. 